
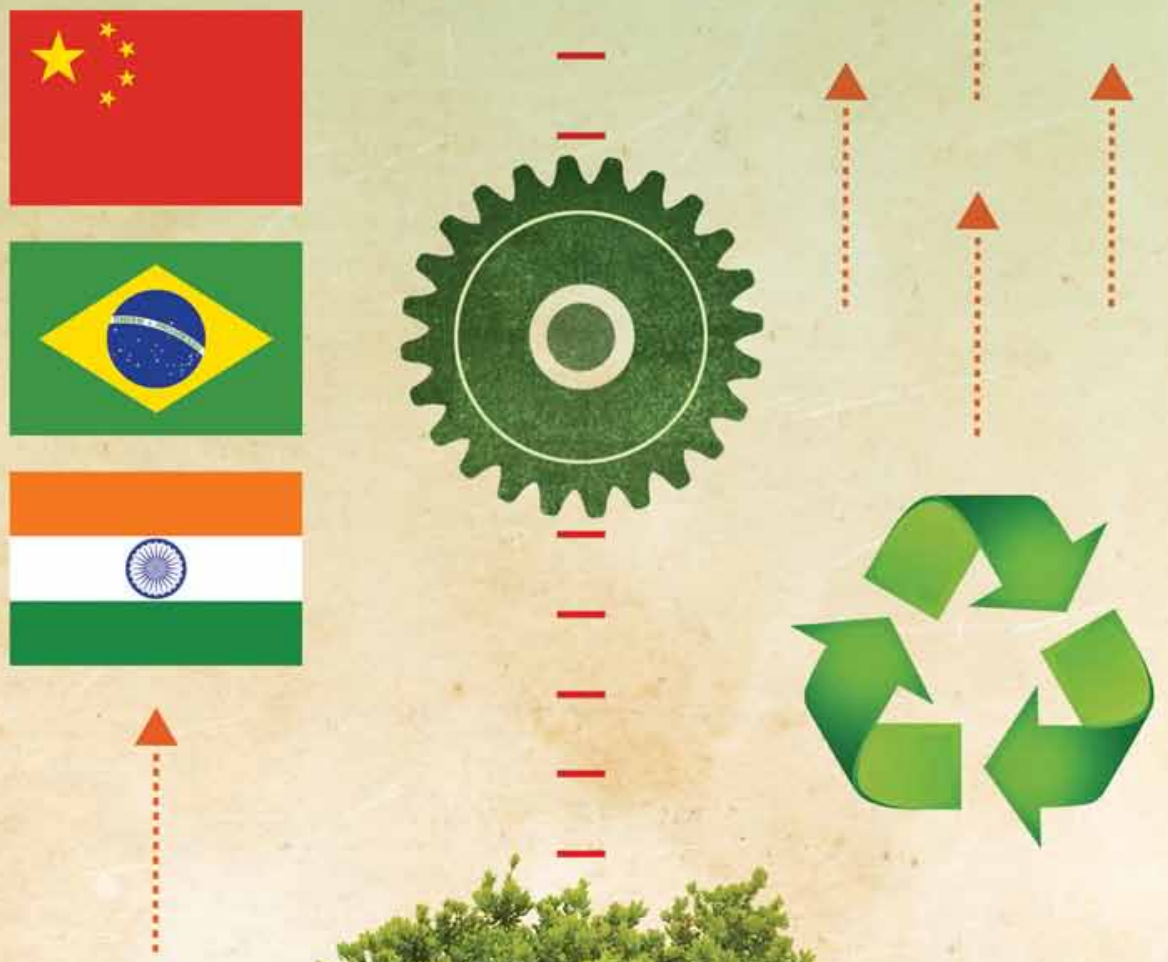

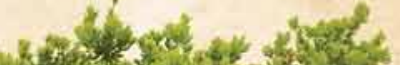

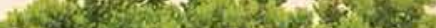

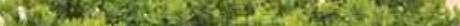

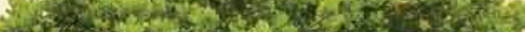

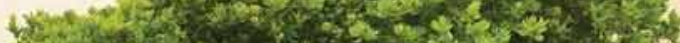

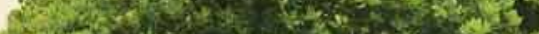

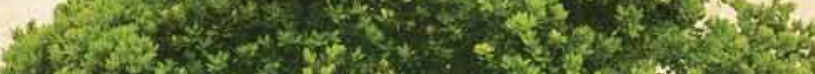

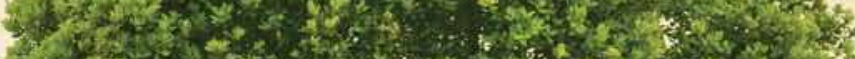

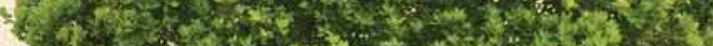

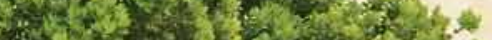

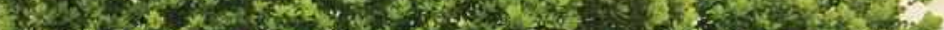

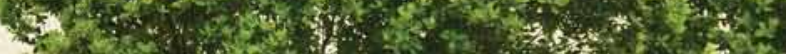

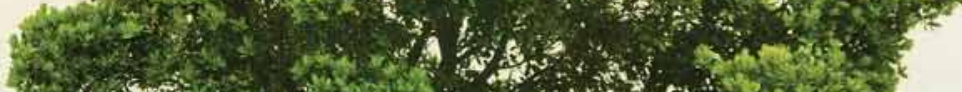

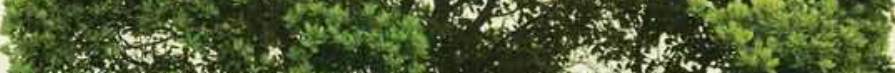

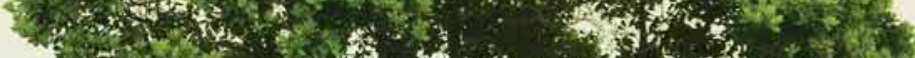

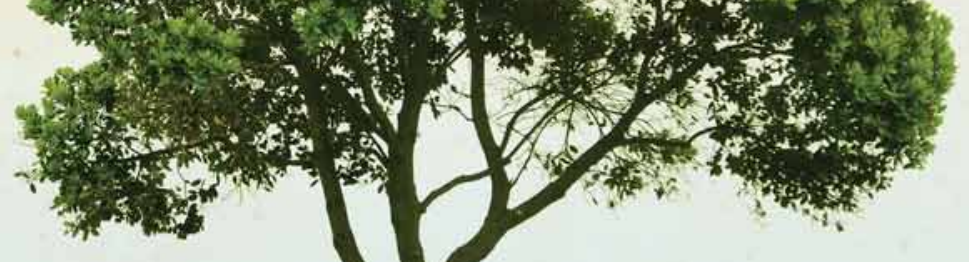




\title{
Os Bics e o Desenvolvimento Verde: como a China está forjando um novo modelo de desenvolvimento verde que o Brasil, a Índia e outros já estão copia̛ndo*
}

\author{
The BICs and green development:How \\ China is forging a new green \\ development model that Brazil, India and \\ others are already emulating
}

John A. Mathews

\section{Resumo}

Brasil, Índia e China (os BICs) estão orquestrando uma 'Grande Convergência' que vai de encontro aos dois últimos séculos da Grande Divergência que os separou do Ocidente. Nesse processo, os BICs estão tirando bilhões de pessoas da pobreza. Mas o modelo do capitalismo industrial que serviu tão bem ao Ocidente, e que mostrou ser um modelo também para os BICs, simplesmente não "se ajustará" para atender às aspirações de tantos. $O$ modelo de industrialização que se apodera de recursos, e expande linhas de suprimento através de conquista armada, simplesmente não está disponível para os $\mathrm{BICs}$, nem eles podem ter confiança em um modelo que os prende à dependência de combustível fóssil indefinidamente, mesmo que os suprimentos de petróleo e carvão cresçam e depois declinem, e as emissões de carbono se acumulem. Portanto, um novo modelo de capitalismo industrial tem de ser desenvolvido, e está sendo desenvolvido pela China em primeira instância, à medida que ela forja novos arranjos institucionais e novas estratégias de industrialização, baseadas em energias renováveis e tecnologias de baixa emissão de carbono; em iniciativas de economia circular; e em ecofinanças. Essas novas estratégias e instituições - na verdade, um novo modelo verde de capitalismo industrial - estão sendo forjadas enquanto a China também aumenta sua energia fóssil e demanda por suprimentos. Esse modelo verde de desenvolvimento, que envolve estabilidade, resiliência e segurança, oferecerá um atraente modelo para outros países, preferencialmente ao "engodo" do desacreditado Consenso de Washington - e em particular para o Brasil e a Índia, que já deram início a uma mudança com relação a uma estratégia de desenvolvimento verde. A grande pergunta não respondida, tanto para si próprios quanto para o mundo, é se eles irão sucumbir ao'lock-in de carbono', como seus predecessores ocidentais.

Palavras-chave: estratégias de desenvolvimento verde, estratégias de industrialização, China, India, Brasil, energias renováveis

\begin{abstract}
Abtract
Brazil, India and China (the BICs) are orchestrating a 'Great Convergence' which meets the last two centuries of the Great Divergence that separated the West. In this process, the BICs are taking billions out of poverty. But the model of industrial capitalism that served so well in the West, and that also proved to be a model for BICs, will Just not fit to meet the aspirations of so many. The industrialization model that takes hold of resources, and expand supply lines through armed conquest, is simply not available to the BICs, nor can they have confidence in a model that relates to the dependence on fossil fuels indefinitely, even if the supplies petroleum and coal grow and then decline, and carbon emissions accumulate. Therefore, a new model of industrial capitalism has to be developed, and is being developed by China in the first instance, as it forges new institutional arrangements and new industrialization strategies based on renewable energy technologies and low carbon; in initiatives of circular economy, and in ecofinance. These new strategies and institutions - indeed, a new green model of industrial capitalism - are being forged while China also increases their demand for fossil fuel and supplies. This model of green development, which involves stability, resilience and security, provide an attractive model for other countries, preferably the "deception" of the discredited Washington Consensus - and in particular to Brazil and India, which have already initiated a shift with against a green development strategy. The big unanswered question, both for themselves and for the world, is whether they will succumb to the 'carbon lock-in', like its predecessors Westerners.
\end{abstract}

Key words: green development strategies; industrialization strategy; China; India; Brazil; renewable energies

Professor of Strategy, Macquarie Graduate School of Management, Macquarie University, Sydney NSW 2109 Australia, Tel +612 9850 6082, Email john.mathews@mgsm.edu.au,Web http://www.mgsm.edu.au/research-and-faculty/faculty/ professor-john-mathews/ Eni Chair of Competitive Dynamics and Global Strategy7, LUISS Guido Carli University, Viale Romania 3200197 Roma Italy. Tel +3906 8522 5504, Email: jmathews@luiss.it, Web: http://docenti.luiss.it/mathews

* Paper preparado para Conferência 'Novas perspectivas econômicas de pensamento, ensinamento e política - Uma perspectiva brasileira dentro de um diálogo global', Rio de Janeiro, Brasil, 7-9 novembro 2011. 


\section{Introdução}

$\mathrm{O}$ capitalismo industrial revelou ser o mais poderoso agente de transformação existente atualmente no mundo. Seu aparecimento na Grã-Bretanha, na segunda metade do século dezessete, criado através do acesso aos novos combustíveis fósseis, desencadeou ganhos fantásticos na produtividade associados aos aumentos de renda e foi, portanto, copiado por todo o mundo. Karl Polanyi (1944) chamou a isso a 'Grande Transformação', no sentido de que nada seria o mesmo a partir daí. O capitalismo foi na verdade uma incrível invenção da humanidade. Seu aparecimento nas cidades levou a demandas de independência e liberdades que hoje são consideradas naturais no Ocidente, e que estão agora se espalhando pelo mundo inteiro. Foi introduzido na Revolução Industrial, que utilizou combustíveis fósseis na produção de bens, juntamente com novas invenções mecânicas, lançando assim o mundo em uma trajetória de industrialização e modernização, que está trazendo um número cada vez maior de pessoas para sua órbita.

O sistema industrial utilizado ao longo dos três últimos séculos está agora sendo "expandido" - para acomodar a subida de novos poderes industriais, como a China, a Índia e o Brasil e outros países do"mercado emergente". O impacto do sistema industrial sobre seu cenário ecológico - o'meio ambiente' - pôde ser mais ou menos ignorado na fase inicial de expansão industrial, mas hoje que envolve toda a terra não é mais uma opção exeqüível. O mais preocupante é o impacto global do capitalismo industrial sobre o cenário natural, e a violação dos seus limites naturais - particularmente com relação aos países que hoje buscam ocupar seu lugar no mundo industrializado. $O$ conceito de que o capitalismo industrial estava dominando o planeta e destruindo não só sua própria base de recursos como também toda a biosfera foi se tornando palpável na primeira década do século vinte e um, quando se tornou claro que embora a China, em particular, tivesse atingido níveis fantásticos de crescimento com relação às décadas anteriores estava também destruindo seu próprio meio ambiente a um custo terrível para seus habitantes e para o mundo como um todo.

No seu livro mais recente, The Next Convergence, Michael Spence (2011) prestou um serviço ao mundo ao declarar que no período atual está emergindo um novo padrão de crescimento, no qual a divergência entre rendas e riquezas que caracterizou os dois primeiros séculos está sendo revertida, e países gigantes como a China e a Índia começam a se aproximar do Ocidente. ' Spence prevê uma distinta possibilidade de $75 \%$ da população mundial estar vivendo em 2050 com certo conforto - quando apenas 15\% tinha tal status no ano de 1950.

Voltemos às declarações de Spence quanto às projeções reais, levando o crescimento da população mundial de agora até 2050 a 8 bilhões; e dentro desse "pacote", o número de pessoas tiradas da pobreza (liderados pela China e Índia) subindo de 1 bilhão em 2000 para 6 bilhões (i.e. 75\%) em 2050. Esse gráfico, que preparei com meu colaborador Dr Hao Tan, é apresentado na Figura 1. As dinâmicas 
dessa progressão são criadas a partir de uma curva externa convexa representando o limite de crescimento global (As Nações Unidas revisaram as projeções populacionais para o século vinte e um), e uma curva interna logística representando a rápida mudança de boa parte dessa população para uma classe média global.

Fig. 1. População mundial: Como poderia haver 6 bilhões de pessoas com renda média até 2050 A população mundial e a renda média População: 2010-2100

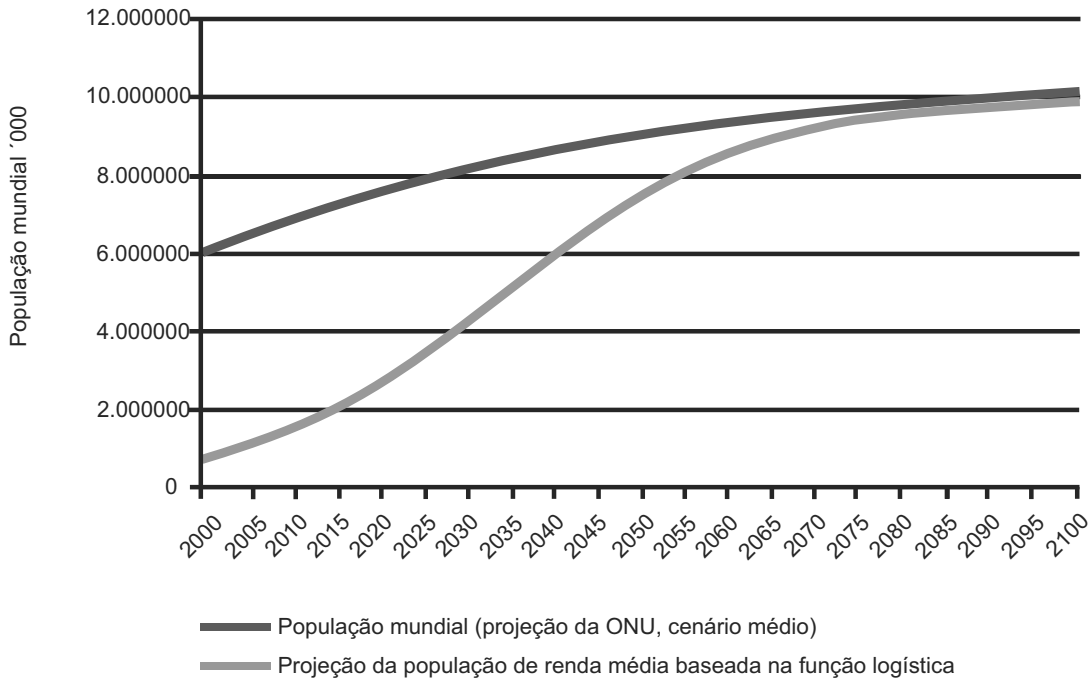

Nota 1: Todas as informações sobre população são projeções da ONU (cenário médio) (disponível em: http://esa.un.org/undp/wpp/index.htm

Nota 2: A projeção da população mundial de renda média é baseada na suposição de que em 2050 a população de renda média irá representar $75 \%$ da população global.

Seis bilhões de pessoas tiradas da pobreza - hoje apenas um bilhão de pessoas vive com uma renda média! Que meta extraordinária - e que conquista se na verdade isso ocorrer! Que triunfo para nossa civilização capitalista industrializada!

Mas aí está o problema. O modelo do capitalismo industrial que se desenvolveu pelo e para o Ocidente - pela Grã-Bretanha, Europa, Estados Unidos e finalmente Japão - permitirá uma expansão seis vezes maior da sua energia e impacto sobre recursos naturais em um planeta já em degradação? O número de carros no planeta poderá ser aumentado, passando de menos de um bilhão para quatro ou cinco bilhões? As vastas indústrias de aço e cimento que estão construindo a infraestrutura da China e da Índia poderão sextuplicar-se ou mais? Poderão...?

Perguntas feitas dessa forma são respondidas por si mesmas. O modelo ocidental não "se ajusta" para acomodar as aspirações do Brasil, Índia e China e todos 
os outros povos que esperam sua vez de gozarem os frutos da industrialização. O congestionamento urbano, a poluição, a geração de lixo, as demandas por combustíveis fósseis, as guerras por recursos que teriam de ser travadas para expandir e defender as linhas de suprimento de petróleo, sem mencionar o impacto do aquecimento global por emissões de carbono continuadas e expandidas - enumerar essas conseqüências de expansão do caminho do "business as usual" é revelar porque esse modelo não "se ajustará". É na realidade uma "verdade inconveniente".

Houve quem interpretasse isso dizendo que as promessas de industrialização não podem ser cumpridas. O biólogo Garrett Hardin (1968), por exemplo, que criou uma bela "parábola" sob a forma da "tragédia dos comuns", também criou uma parábola feia sob a forma da "ética salva-vidas". Hardin argumentou que a "liberdade de procriar" é a mais tóxica das nossas liberdades, e o crescimento populacional exponencial estaria envenenando o planeta. Muitos outros biólogos recomendaram uma solução para o problema de 'ajuste" do modelo ocidental de industrialização por meio de redução populacional, considerada a ameaça básica. Não é dito se será a guerra, as doenças ou a fome o grande agente dessa redução.

Mas há outra linha de entendimento, que parece ser favorecida pelos governos que têm mais a perder com essa "verdade inconveniente" e que também investiram muito para encontrar uma solução. Essa linha baseia-se em construir uma alternativa ao modelo ocidental de capitalismo industrial, e em mudar as regras e as instituições que moldam e apoiam as políticas adotadas em qualquer época específica. É o desenvolvimento de uma mudança global, que a partir do trabalho de acadêmicos chineses como Hu (2006), proponho que seja chamado de Modelo do Desenvolvimento Verde. Neste paper descrevo seus elementos, as razões para seu aparecimento, e seus objetivos.

\section{A Grande Convergência}

Os gráficos da Fig. 2 (de Martin Wolf do Financial Times) mostram em que extensão a China está agora convergindo ao Ocidente no século vinte e um - i.e. invertendo a Grande Divergência anterior (Pomeranz 2000). A Fig. 2a mostra que a China sobrepujou todas as economias mundiais em termos de crescimento do PIB no século vinte e um. A Fig. 2b mostra como a China está seguindo os passos do Japão e da Coréia, diminuindo o gap com relação aos Estados Unidos em termos de renda per capita. O gráfico indica que a performance anterior do Japão e da Coréia é a trajetória que a liderança chinesa pretende claramente seguir. Como diz Martin Wolft, essa 'grande convergência' que está invertendo a 'grande divergência' prévia é "de longe o maior fato isolado com respeito ao nosso mundo".2

A China alimentou essa transformação através do seu domínio crescente do comércio mundial. O gráfico 2c mostra que no caso do comércio do Brasil, suas exportações para a União Européia mantiveram-se firmes enquanto as exportações 
Fig. 2a. A grande convergência.: as economias emergentes sobrepujam as demais Crescimento do PIB (média móvel de 10 primeiros anos)

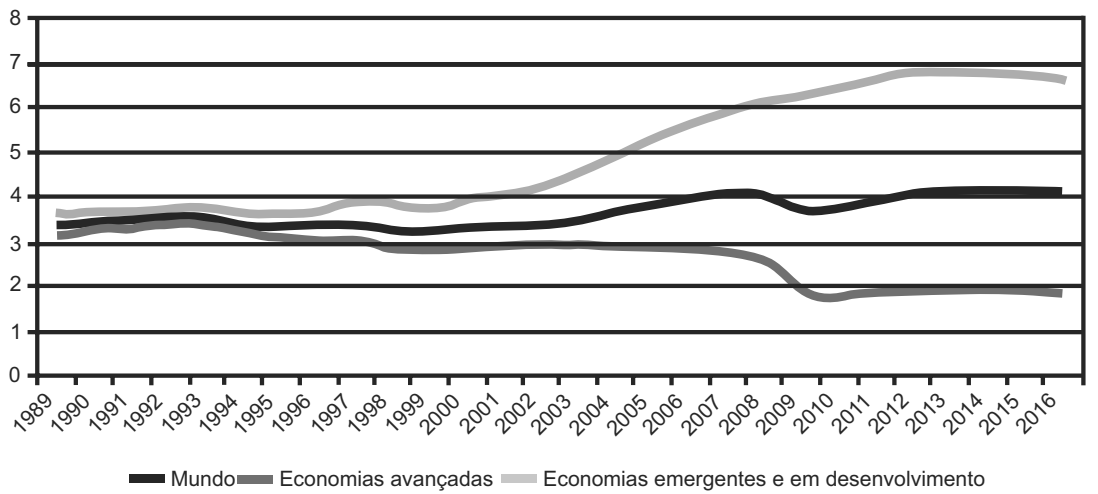

Fonte: http://www.ft.com/intl/cms/s/0/072c87e6-1841-11e0-88c9-00144feab49a.html\#axzz26sro6ZI2

Fig. 2b. A convergência asiática em termos do PIB per capita A convergência asiática (relativo ao PIB norteamericano por pessoa)

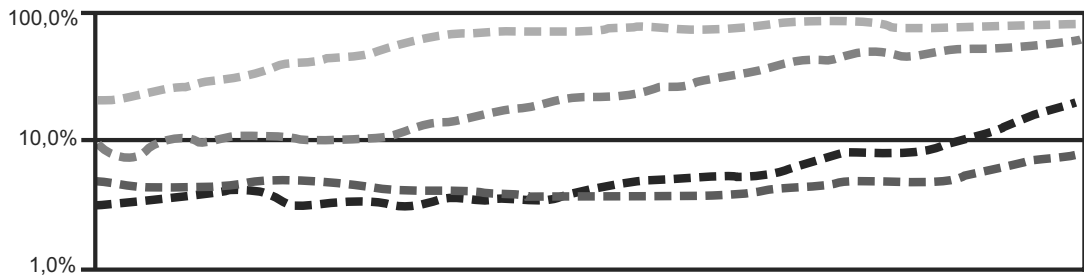

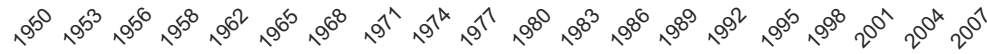

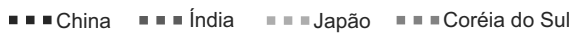

Fig. 2c. Exportações do Brasil para a União Europeia, Estados Unidos e China (\%)

A grande convergência: quotas de exportação

Quotas de exportação

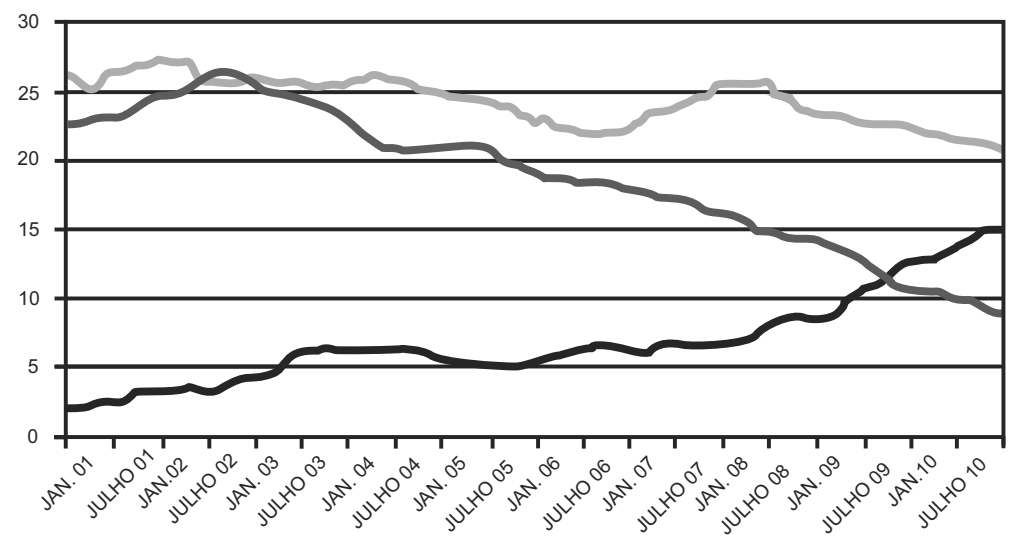


para os Estados Unidos declinaram (relativamente), mas suas exportações de matéria prima para a China vêm crescendo com constância (relativa) ultrapassando o percentual de exportação para os Estados Unidos em 2009 e chegando a 15\% das exportações do Brasil em 2010. Acadêmicos brasileiros mencionam atualmente o posicionamento do Brasil em um "mundo sinocêntrico' - indicando com que quê rapidez eles fizeram o ajuste intelectual. ${ }^{3}$

\section{Por que o modelo industrial ocidental não "se ajustará"}

Assim como a China, a Índia e o Brasil aumentam sua participação na exploração dos recursos mundiais para alimentar suas máquinas industriais que se expandem cada vez mais, e buscam o crescimento de dois dígitos, aumentando o seu impacto sobre os recursos do planeta - e com isso sua vulnerabilidade (Figs $3 a$ e - b).

As restrições com que a China está se desenvolvendo industrialmente são muito bem ilustradas pela sua crescente dependência das importações de petróleo - uma dependência desastrosa, tanto em termos das somas que têm de ser pagas por essas importações como a insegurança no que tange à energia que isso acarreta. Quanto mais os países como a China e a Índia se tornam dependentes das importações de petróleo, enquanto os próprios países ocidentais (Estados Unidos e Europa) e o Japão permanecem dependentes das importações de petróleo, mais o mundo se encaminha para um século de guerras por recursos e guerras pelo petróleo no século vinte e um. Hoje se sabe que a guerra do Iraque, iniciada no governo de Bush (filho) em 2003, teve em grande parte a intenção de assegurar linhas de suprimento de petróleo

Fig. 3a. O crescente gap de petróleo da China

A questão energética e o desenvolvimento: o iminente gap energético e de petróleo da China

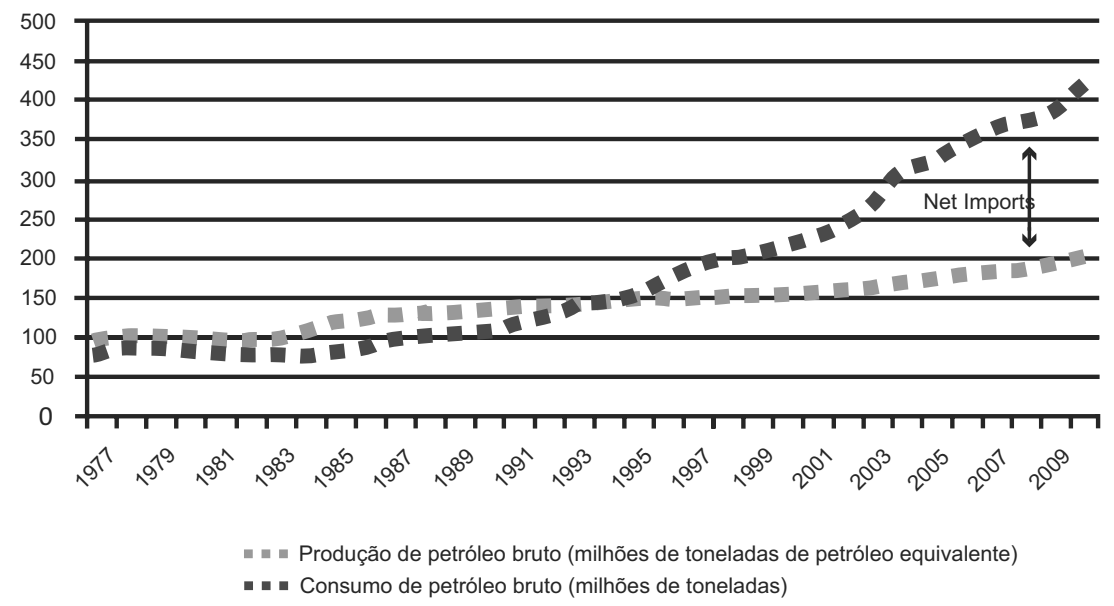


para os Estados Unidos -- como ocorreu anteriormente na guerra do Golfo, iniciada no governo de Bush (pai) em 1991. Em ambos os casos a China e a Índia estavam preparadas para assumir um papel passivo - mas esse não poderá ser o caso no futuro. O gráfico seguinte mostra que o problema da Índia de importação de petróleo (ou o gap entre produção e importação de petróleo) é ainda pior que o da China. China e Índia estão se aproximando do desastre -- com o aumento dos preços do petróleo, a vulnerabilidade de um número de fornecedores de petróleo, e a exacerbação das tensões com os países industrializados e seu "lock-in de carbono" (Unruh 2002).

Fig. 3b. O crescente gap de petróleo da Índia

A questão energética e o desenvolvimento: $O$ crescente gap de petróleo/ energia da Índia

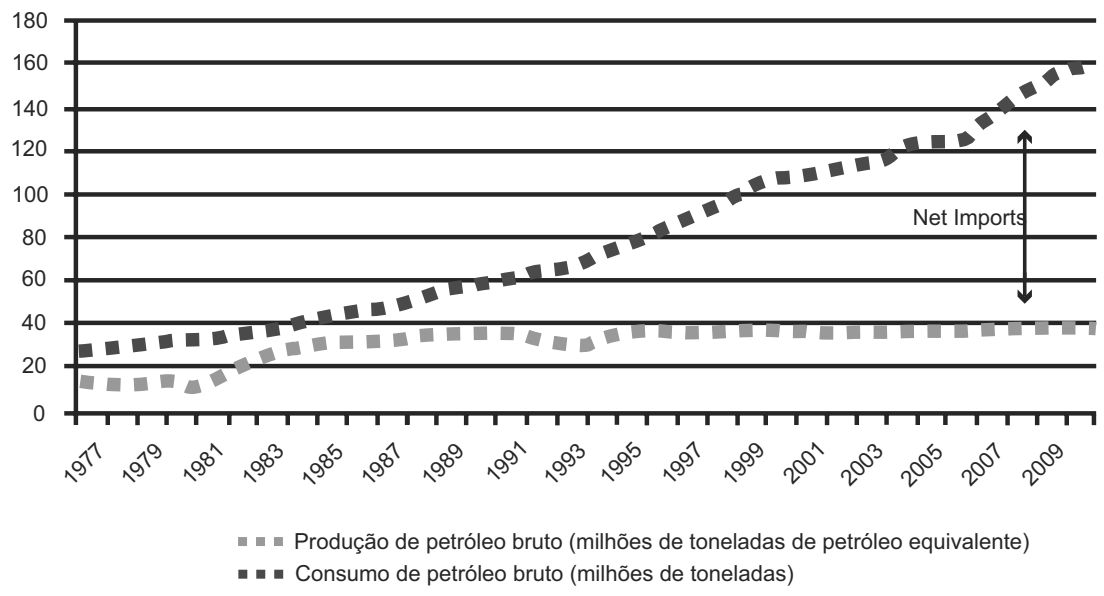

\section{Um novo modelo de desenvolvimento verde emergindo: China, Índia e Brasil}

O modelo ocidental de capitalismo industrial desenvolveu-se através de três tipos de mercados - e serão necessárias mudanças nesses mercados e não políticas genéricas, como impostos sobre emissões de carbono e mercado de créditos de carbono, para levar a cabo a transformação sustentável. Grandes mudanças já estão a caminho - nos sistemas de energia (dos combustíveis fósseis aos renováveis); nos recursos e mercados de commodities (da economia linear à economia circular); e nas finanças (das finanças genéricas para finanças ligadas ao ecossistema). A meu ver esses são os grandes mercados exigidos para pôr um sistema industrial global em alinhamento com seu cenário ecológico, oferecendo aos BICs e outros países um novo caminho de Desenvolvimento Verde.

Em primeiro lugar, pelo fato da energia ser tão importante como sustentáculo de todo o edifício industrial, e a queima de combustíveis fósseis ter criado um grande 
problema, as mudanças nos mercados de energia - substituindo combustíveis fósseis por fontes de energia renovável -- são de extremo interesse. A meu ver, os mercados de energia estão realmente "esverdeando" e mudando de combustíveis (que são queimados) para energia de recursos renováveis (que são cultivadas). É uma mudança de combustão para energia limpa. A utilização de fontes de energia renovável, na qual a energia tem de ser "ganha" através de projeto e implementação de tecnologias sofisticadas, levará sem dúvida a um maior senso de responsabilidade e moderação. $A$ mudança para fontes de ER está a caminho, mas poderia ser acelerada pelo uso mais firme de instrumentos capitalistas e instrumentos políticos - por inovações financeiras, como "climate bonds", que podem dar o "grande impulso" necessário para construir vastos sistemas de energia renovável no mundo em desenvolvimento.

Em segundo lugar, o amplo consumo de recursos naturais no atual sistema capitalista industrial, um processo que está literalmente "engolindo" a terra e que nos força a agir como violadores da natureza está avançando contra seus limites naturais. Os novos 'green shoots' de uma abordagem alternativa, que envolve o rastreamento de commodities através de sua circulação e recirculação no sistema global, estão emergindo. Serão as mudanças nos mercados de commodities, que irão direcionar a recirculação de materiais e levar a uma nova concepção de uma Economia Circular, em que os resíduos de um produtor tornam-se inputs para outro -- em oposição à concepção de Economia Linear, em que matérias primas são utilizadas de um lado e os resíduos são descartados de outro. Essas mudanças serão conduzidas por mudanças de cima para baixo nas concepções das políticas e também por mudanças do comportamento do consumidor, que são traduzidas em uma produção intensiva de baixo carbono e recursos, propagada por toda a extensão da cadeia de valores.

$E$ em terceiro lugar, são os bancos e os mercados financeiros que estão desenvolvendo novos conceitos de 'finanças verdes' que levarão esses "new shoots" (novos rumos) aos mercados de energia e materiais. Novos veículos de investimento dirigidos, conhecidos como títulos Verdes ou climate bonds, terão o efeito de mudar padrões de investimento - de projetos ligados a combustíveis fósseis a projetos com menor impacto de carbono e recursos naturais. As finanças passarão a focalizar projetos de investimento verde caracterizados por seu valor ecológico e pela credibilidade do emprestador, em detrimento das abordagens tradicionais que se tornarão identificadas simplesmente como "genéricas". Isso porque os ecoprojetos provavelmente oferecerão um futuro mais seguro que aquele baseado na destrutividade dos combustíveis fósseis. Os investidores de atacado, como fundos de pensão e trustes de seguro, já estão seguindo essas novas direções.

São as interconexões entre essas tendências que as deixarão autofortalecidas e autodifundidas, enquanto os "new shoots" da economia verde crescem e ligam-se uns aos outros através do modelo competitivo. A meu ver, isso gerará um tipo diferente de crescimento, intensivo e não extensivo, em que as operações capitalistas gerarão crescentes retornos sem estender a base de recursos. Seria na verdade um tipo 
diferente de capitalismo industrial. Seus traços fundamentais já estão emergindo. Podem-se ver suas linhas gerais na transformação da economia verde que está surgindo, inicialmente na China e depois, em certa extensão, na Índia e no Brasil.

\section{China}

Depois de 2001, quando passou a fazer parte da OMC, a China construiu o maior sistema manufatureiro do mundo, movido pelo maior sistema de energia.- e alimentado, majoritariamente, por carvão e outros combustíveis fósseis. Em 2010 a capacidade de energia elétrica da China ultrapassou 1 TW (1000 GW). A China está seguindo os passos dos primeiros industrialistas, da Grã-Bretanha à Europa e aos Estados Unidos e, no século vinte, dos tigres do leste asiático -- como Japão, Coreia e Taiwan. Todos esses países utilizaram combustíveis fósseis para construir seus fantásticos sistemas industriais. A China está fazendo isso em escala mais ampla que qualquer outro país - acrescentando 50 bilhões de watts de energia elétrica à base de carvão a cada ano (ou uma usina de energia térmica de $1 \mathrm{GW}$ por semana) e "cavucando" o mundo em busca de carvão, petróleo e gás. Seu rápido aumento de geração de energia elétrica a partir de combustível fóssil está seguindo um curso bem conhecido. (Fig. 4a).

Hoje a China reconhece que essa estratégia não "se ajustará" porque exigirá produção de carvão e importação de petróleo que violarão de forma aberta e agressiva as necessidades de outros países, levando inevitavelmente à guerras por recursos. A China está tentando evitar esses confrontos, construindo suas indústrias de ER o

Fig. 4a. A face negra da China: consumo crescente de energia térmica

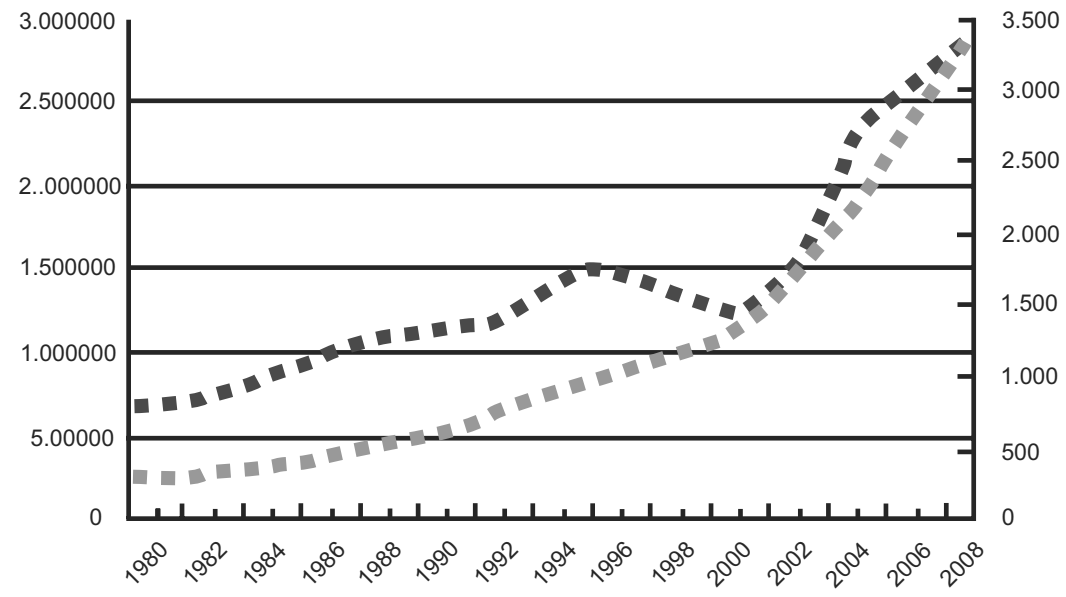


mais rápido possível, até agora com incrível sucesso. Na energia eólica, por exemplo, saiu de uma posição marginal em 2005 e vem dobrando sua capacidade a cada ano, a ponto de ter se tornado líder mundial ao final de 2010 (Fig. 4b).

Fig. 4b. A face "verde" da China: desenvolvimento de energia eólica

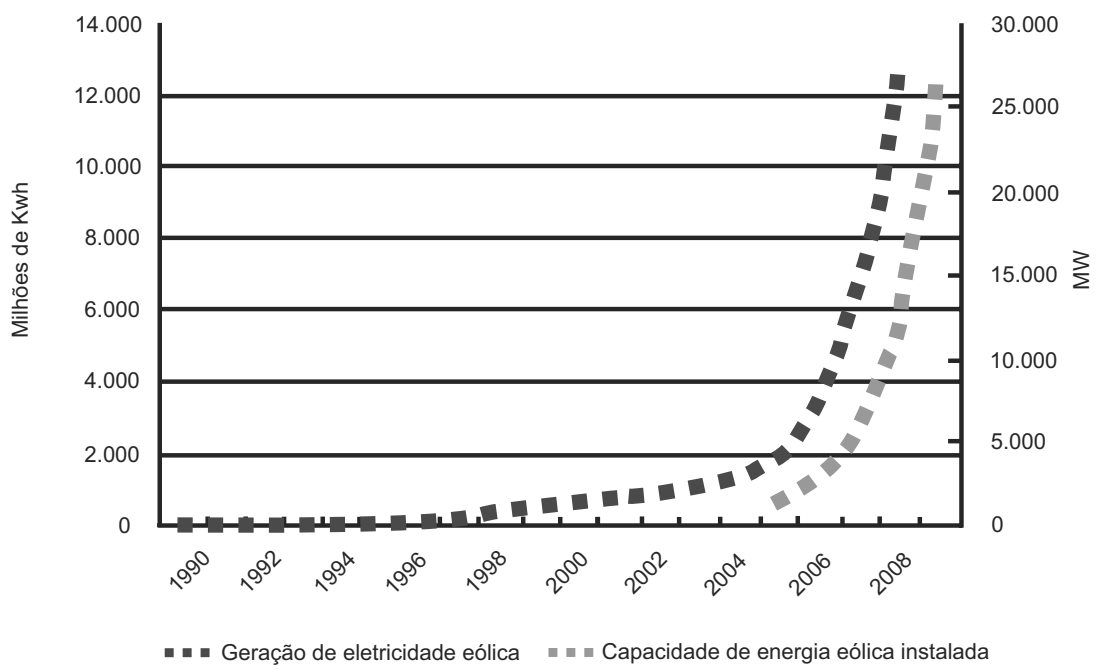

Em 2010 a China estava adicionando mais capacidade de geração de energia, a partir de fontes hidráulica, nuclear e "novas" fontes renováveis, que de usinas térmicas convencionais - um marco extremamente importante para a China e para o mundo. Seu $12^{\circ}$ Plano Quinquenal tem metas notáveis para elevar esses níveis. Em termos de energia elétrica, sua liderança, através de um organismo de planejamento - o National Development and Reform Commission (NDRC) - prevê que a capacidade de energia elétrica será da ordem de 1,6 TW até 2020, sendo 500 GW (0,5 TW) gerados por fontes renováveis - hídrica, eólica, solar - i.e. renováveis representando $30 \%$ da geração de energia elétrica até 2020. Nesse ínterim, a meta do $12^{\circ}$ Plano Quinquenal é que as renováveis (solar, eólica, hídrica) respondam por 11,4\% das fontes primárias de energia até 2015 (Mathews 2011b).

Portanto, apesar da dependência chinesa à expansão de combustível fóssil continuar acelerada, ao ritmo de uma usina térmica (movida a carvão) de $1 \mathrm{GW}$ por semana, cada vez mais esse investimento está se equiparando aos gastos em renováveis. O perfil do setor energético já está mudando, e uma forte composição está sendo criada, prometendo levar maior desenvolvimento e expansão ao setor de renováveis. $\mathrm{O}$ aporte da China aos renováveis é inteiramente pragmático, guiado por assuntos de segurança nacional, mas tem implicações nos efeitos ambientais e, em particular, no que concerne ao aquecimento global. As emissões de particulados de 
carbono na China (tornando o ar das cidades industriais praticamente irrespirável) continuam a subir, mas espera-se que cheguem a um nível estável na década de 2020 e então passem a declinar, à medida que fontes mais limpas de energia sejam utilizadas (carvão "limpo" e recursos renováveis). E também espera-se que as emissões de carbono geradoras de efeito estufa continuem subindo, mas deverão atingir um nível estável nas décadas de 2020 ou 2030, quando passarão a declinar - um declínio significativo (Mathews 2011b).

Ao mesmo tempo, o desenvolvimento ecoindustrial na China está se acelerando e hoje promete tornar-se um dos principais modelos de desenvolvimento industrial a serem seguidos. As iniciativas ecoindustriais pretendem solucionar problemas de recursos e de resíduos, encorajando empresas a obter suas matérias primas a partir de resíduos gerados por outras empresas - transformando "resíduos em recursos". Muitas iniciativas ecoindustriais têm sido planejadas e implementadas visando à Economia Circular, desde que esse conceito foi introduzido pela primeira vez por acadêmicos chineses no final da década de 1990. Por exemplo, em 2005 o National Development and Reform Commission, juntamente com cinco outros ministérios, lançou o primeiro grupo de projetos pilotos nacionais de demonstração, enquanto um segundo grupo era iniciado em 2007. ${ }^{4}$ Nesse meio tempo, um programa estabelecido pelo Ministério de Proteção ao Meio Ambiente, juntamente com dois outros ministérios, tinha indicado a criação de um total de 30 Parques Ecoindustriais (EIP) por todo o país até dezembro de 2008, como se vê na Fig. 5.

Não há como enfatizar o suficiente que o conceito de Economia Circular representa uma separação radical da economia linear convencional, em que matérias primas são

Fig. 5. Parques ecoindustriais aprovados na China até dezembro de 2010

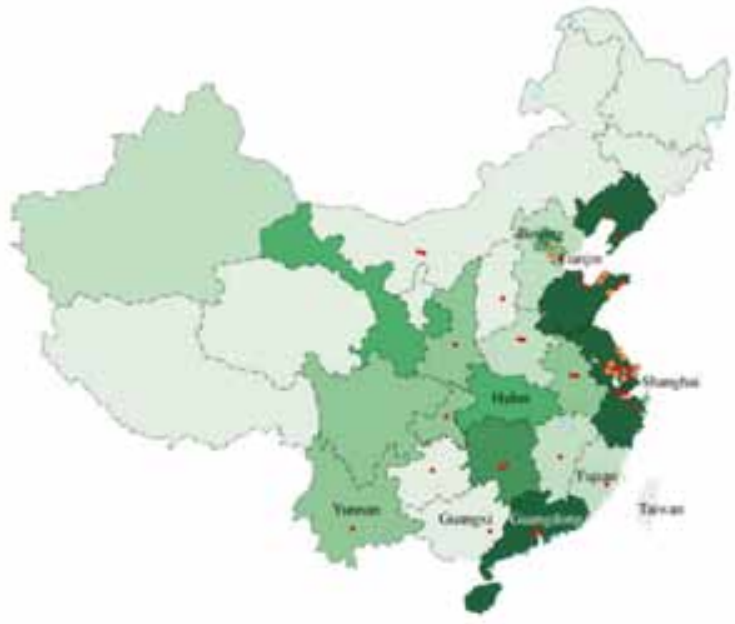


mineradas ou extraídas de um lado e resíduos são descartados em outro - com os dois lados explorando uma bacia chamada 'natureza', sem preocupação ou restrição. Na verdade, o próprio conceito das contas nacionais, medidas pelo Produto Interno Bruto (PIB), é típico de economia linear. 'Crescimento do PIB - na ausência de retornos crescentes - significa crescimento da produção. Isso se tornou a religião não-oficial do capitalismo industrial, qualquer proposta que possa interferir com crescimento extensivo, através da interferência no PIB, é considerada inválida. A China até agora vem mantendo a estrutura básica de contabilidade do PIB, enquanto, sub-repticiamente, constrói uma "economia circular" alternativa de ligações ecoindustriais. ${ }^{5}$

Em terceiro lugar, a China está redirecionando seu sistema financeiro para ecofinanças, ou finanças verdes. De acordo com o $11^{\circ}$ Plano Quinquenal (entre os anos de 2006 e 2010) e o $12^{\circ}$ atual (entre 2011 e 2015), os bancos estatais chineses estão sendo direcionados para refrear os investimentos nos setores de "consumo intensivo de energia e recursos naturais", sob pena de sanções financeiras, e favorecer empréstimos às indústrias estratégicas verdes emergentes, que foram favorecidas no $12^{\circ}$ Plano Quinquenal. Por exemplo, o China Development Bank (CDB) vem aumentando drasticamente seus empréstimos para o setor verde emergente, de 83 bilhões de yuans em 2008 para 175 bilhões de yuans em 2009, e 232 bilhões de yuans em 2010 - para projetos caracterizados como de economia de energia e para medidas de proteção ambiental. O Agricultural Bank of China ( $A B C)$ vem ampliando seus empréstimos para projetos verdes e diminuindo-os para 12 setores de alta energia; no final de 2010 os novos empréstimos concedidos a esses setores não-preferenciais foram $4,4 \%$ mais baixos que o aumento médio de empréstimos corporativos pelos bancos do mundo, enquanto a proporção de empréstimos bancários a esses setores declinou de 15,9\% em 2008 para 14,5\% em 2009 e apenas 13,5\% em 2010. ${ }^{6}$

Essas iniciativas são todas respaldadas por uma legislação forte (como a Lei de Energia renovável de 2006, que introduziu tarifas de feed-in na China e a lei de Economia Circular de 2008), e pela tendência ao desenvolvimento verde no $11^{\circ}$ Plano Quinquenal e mais recentemente no $12^{\circ}$. Esses instrumentos de planejamento e as iniciativas de política e estratégia coerentes com eles, combinadas com um forte encorajamento do estado e cumprimento da nova direção, significam que a promoção do modelo de Desenvolvimento Verde na China não é casual nem acidental.

\section{Brasil e Índia}

Há alguns desenvolvimentos comparáveis no Brasil e na Índia, indicando que esses dois países já embarcaram em um processo que poderia ser descrito com uma mudança para um modelo de desenvolvimento verde.

Brasil: As recentes iniciativas do governo brasileiro tiraram 40 milhões de pessoas da pobreza, e o país pôs em foco o desenvolvimento verde durante a conferência Rio+20 sobre desenvolvimento sustentável realizada em junho de 2012. O Brasil 
já é um grande usuário dos recursos de energia renovável, retirando $85 \%$ de suas necessidades de consumo a partir de fontes renováveis, sob a forma de energia hidráulica no setor de produção de energia elétrica e de biocombustíveis no setor de transporte. Segundo o Balanço Nacional de Energia do Brasil em 2008, a capacidade total de energia elétrica era de pouco mais que $100 \mathrm{GW}$ (cerca de 1/10 da capacidade da (hina) dos quais $78 \mathrm{GW}$ eram de energia hidráulica, $23 \mathrm{GW}$ de usinas convencionais movidas a carvão, 2 GW de energia nuclear e apenas $414 \mathrm{MW}(0,4 \mathrm{GW})$ de energia eólica. Em termos de produção de biocombustível de cana de açúcar, o Brasil é o líder mundial, com um programa moldado pelo governo que remonta à década de 1970 (o "Pró-alcool"), que inclui o uso compulsório de uma mistura de gasolina com etanol. Isso gerou uma imensa indústria rural de plantação de cana de açúcar para produção de etanol e também de açúcar. As vantagens comparativas do Brasil nessa produção - terra, sol e mão de obra barata - foram potencializadas pelos próprios esforços de P\&D do país, que resultaram no desenvolvimento de melhores variedades de safras e conhecimento do solo - o que levou a redução dos custos de produção, tornando o etanol brasileiro mais barato que a gasolina.? Isso demonstra que os países em desenvolvimento podem obter benefícios das energias renováveis e biocombustíveis acrescentando seus próprios esforços de $P \& D$ e inovações às tecnologias copiadas do mundo desenvolvido - desde que sigam estratégias sensatas e não utilizem áreas sensíveis como a Floresta Amazônica, para produção de biocombustíveis.

Em dezembro de 2009 a Agência Nacional de Energia Elétrica (ANEEL) realizou o primeiro leilão de energia eólica do país, oferecendo 1,8 GW de contratos de fornecimento de energia para usinas eólicas, com entrega a partir de julho de 2012. ${ }^{8}$ Essas concessões de energia eólica constituem uma inovação institucional aparentemente seguindo o modelo dos leilões de concessões de biodiesel do Brasil e de concessões de energia eólica da China.

A Associação Brasileira de Energia Eólica, respaldada pelo governo, propôsse uma meta de chegar a $10 \mathrm{GW}$ de capacidade de energia eólica até a década de 2020. ${ }^{9}$ Um Plano Energético de Dez Anos foi recentemente publicado pela Empresa de Pesquisa Energética do Brasil (EPE), o departamento de pesquisa do Ministério de Minas e Energia. Prevê uma expansão de $60 \%$ de demanda energética na próxima década e investimento de R\$ 190 bilhões (US\$122,6 bilhões), dos quais 100 bilhões se destinariam a contratos de energia renovável (55\% em hidráulica e $45 \%$ em eólica, biomassa e pequenas centrais hidroelétricas - PCH). Portanto, o Brasil está dando passos decisivos para elevar ainda mais o perfil de energias renováveis no seu sistema energético, embora permita que a Petrobras explore depósitos de petróleo offshore e faça do Brasil um grande exportador de petróleo. ${ }^{10}$

Índia: A Índia também está seguindo uma estratégia avançada de energia renovável, embora construa sistemas de suprimento de energia fóssil para alimentar seu crescente parque manufatureiro e industrial. Em agosto de 2011, a capacidade da Índia de energia elétrica instalada era de 181,6 GW, sendo $65 \%$ gerada por usinas de 
carvão convencionais, 22\% a partir de recursos hídricos, e 3\% de energia nuclear, além de $10 \%$ de outros recursos renováveis (a maioria eólica e biomassa). Em 2010 a Índia tinha uma capacidade eólica instalada de 14,6 GW (ultrapassando a meta do $11^{\circ}$ Plano Quinquenal de 10,5 GW). Nesse Plano (até 2012) a meta de aumento da capacidade de energia elétrica foi revista para 52 GW, mas é hoje considerada uma meta irreal. Em 2009, o governo anunciou um plano de $\$ 19$ bilhões para produzir $20 \mathrm{GW}$ de energia solar até 2022 (i.e. no final do $13^{\circ}$ Plano Quinquenal). A Energia Solar Concentrada (CSP), em que grande número de lentes e espelhos concentram os raios solares em um trocador de calor, permitindo que seja gerada energia elétrica dia e noite, particularmente promissora. ${ }^{11}$ A Índia já desenvolveu empresas de padrão mundial que fornecem equipamentos de energia renovável, como a Praj que fornece bio-reatores (por exemplo, para produção de bioetanol) e a Suzlon com sistemas de energia eólica (hoje um dos dez maiores fabricantes do mundo). A Suzlon domina o mercado indiano de turbinas eólicas, e em 2010 ultrapassou o marco de 5 GW de instalações de energia eólica. A Suzlon globalizouse, tem uma sede europeia no cluster dinamarquês de energia eólica em Jutland, e produz turbinas eólicas na Índia em um cluster industrial altamente concentrado, localizado em Coimbatore (Mangalore), Tamil Nadu (conhecido como a "Manchester do Sul"). ${ }^{12}$ As inovações institucionais incluem a Indian Renewable Energy Development Agency (IREDA) e um Ministério de Energia Nova e Renovável (MNRE, anteriormente Ministério de Recursos de Energia Não-convencionais), assegurando que energias de fontes renováveis recebam o máximo de respaldo político. Ao mesmo tempo, empresas de energia térmica como a Reliance Energy estão construindo usinas a carvão muito grandes, e recebem apoio substancial do governo (nacional e regional) para isso.

E é dada a largada - países desenvolvidos como a Alemanha, antecipando um setor revitalizado de ER responsável por 35\% da geração de energia elétrica até 2020, e a China estabelecendo uma meta de pelo menos 30\% até 2020. O Brasil e a Índia têm razão de sobra para acelerar sua mudança para uma estratégia de desenvolvimento verde, no rastro das iniciativas de mudança de jogo assumidas pela China. Tanto a China como a Alemanha estão passando para uma posição de liderança mundial em termos de renováveis, e gastando claramente seu superávit comercial para garantir e manter sua liderança nas indústrias de manufatura - no caso, manufatura verde e energia verde.

\section{Por que o novo modelo verde promete mais que o modelo de combustível fóssil}

O acadêmico chinês Hu Angang, membro da Chinese Academy of Social Sciences e altamente influente na liderança do seu país, vem defendendo há vários anos que o desenvolvimento verde é "a escolha inevitável para a China"13 Argumenta que a China está sendo forçada a copiar uma alternativa ao modelo de industrialização que o Ocidente conseguiu perseguir, porque é retardatária e enfrenta uma situação 
econômica internacional já saturada; porque está atrasada quanto à tecnologia de combustível fóssil convencional, mas pode dar um pulo para a liderança da tecnologia verde; porque tem uma população imensa para a qual o modelo tradicional não se ajustaria; porque não pode buscar recursos no exterior através de colonialismo e conquista armada - ao contrário dos seus predecessores do Ocidente; e porque baseando seu modelo de desenvolvimento numa crescente exploração de recursos naturais chegará inevitavelmente a uma carência de recursos (por ex. o pico de suprimentos de petróleo e carvão). Qualquer uma dessas razões constituiria um bom motivo para buscar um desenvolvimento alternativo. No conjunto, e quando combinadas com a perspectiva de enfrentar pressão internacional cada vez maior quanto a emissões de carvão, essas razões são extremas, e na verdade tornam o desenvolvimento verde "uma escolha inevitável para a China" - e por extensão para o Brasil e a Índia. O desenvolvimento verde deve ser visto então como o caminho necessário de industrialização para os BICs. A alternativa são guerras permanentes por recursos, terrorismo, maior insegurança, e dependência de importação de combustíveis cujos preços subirão inevitavelmente.

Em contraste, uma estratégia de desenvolvimento verde oferece vantagens dentre as quais as seguintes podem ser enumeradas. 1) Recorre a abundantes recursos energéticos, e desenvolve tecnologias sofisticadas que podem servir como o centro de novas indústrias orientadas para exportação. 2) Os recursos energéticos renováveis são abundantes e amplamente dispersos, de modo que os BICs não podem ser mantidos reféns de energias fósseis e podem gerar energia abundante para implementar sua estratégia industrial, sem custos de combustível. 3) Os recursos renováveis estão espalhados por todos os países (mas particularmente nos países tropicais), portanto as tensões internacionais são reduzidas. 4) As possibilidades de um salto à frente (leapfrogging) em termos de energias renováveis e tecnologias de baixo carbono existem, particularmente se implementadas com estratégias que explorem os padrões nativos e o mercado doméstico. 5) O desenvolvimento de indústrias verdes pode gerar empregos e subsistência tanto nas regiões rurais quanto nas urbanas, contribuindo assim para um desenvolvimento equilibrado. 6), 0 desenvolvimento verde através de iniciativas de economia circular (por ex. reciclagem) oferece a melhor perspectiva de redução de dependência de importações de recursos e sobrecarga no balanço de pagamentos. Para não falar nas vantagens que o desenvolvimento verde oferece em termos de redução de emissões de carbono. Nesse sentido, o desenvolvimento verde é uma estratégia "sem remorsos" -- oferece uma gama de benefícios tangíveis além da redução das emissões de carbono. Mesmo que os perigos do aquecimento global sejam exagerados (muito pouco provável), os BICs de qualquer forma acumulariam enormes vantagens copiando estratégias de desenvolvimento verde, simplesmente por oferecerem maior confiança, resiliência e segurança. ${ }^{14}$

A grande desvantagem das tecnologias verdes é que elas em geral custam mais que as tecnologias convencionais com combustível fóssil - pelo menos no estágio 
atual de exploração, anterior à chegada dos efeitos de pico. É aí que entra a estratégia. Os BICs e outros países que buscam uma alternativa ao modelo convencional de desenvolvimento precisam encontrar formas de ultrapassar o gap entre os custos correntes que excedem os custos de combustíveis fósseis e as receitas previstas, que diminuirão aquelas a serem geradas pelas tecnologias e indústrias tradicionais. Os instrumentos financeiros podem ser direcionados para esse problema, assim como as políticas domésticas, tais como alteração das estruturas de preços, para que os renováveis se tornem mais vantajosos internamente (por ex. tarifas de feed-in) ou as alternativas fósseis menos vantajosas (por ex. taxação sobre emissão de carbono). As finanças são o coração do capitalismo, sua sala de máquinas, por assim dizer. Podemos imaginar um setor financeiro em que trilhões serão emitidos sob forma de títulos que sejam rotulados como dedicados a financiar a infraestrutura verde. Serão rotulados assim em parte devido à demanda desse financiamento "verde" e em parte porque se tornarão uma fonte de finanças que serão mais baratas que as finanças 'genéricas', podendo ser utilizadas para qualquer propósito, inclusive construção de infraestrutura fóssil.

O problema de todos os investimentos em um novo ramo da indústria, ou novo setor industrial, é o seguinte: as receitas previstas são enormes, mas serão ultrapassadas pelos custos. No caso da transição para os sistemas de Energia Renovável, podemos mostrar o'gap' entre custos e receitas, como apresentado na Fig. $6 .^{15}$

O German Development Bank tem relações de longa data com os bancos nacionais de desenvolvimento, dentre eles de longe o maior é o Banco Nacional do

Figure 6. Gastos e rendas previstas para Energias Renováveis

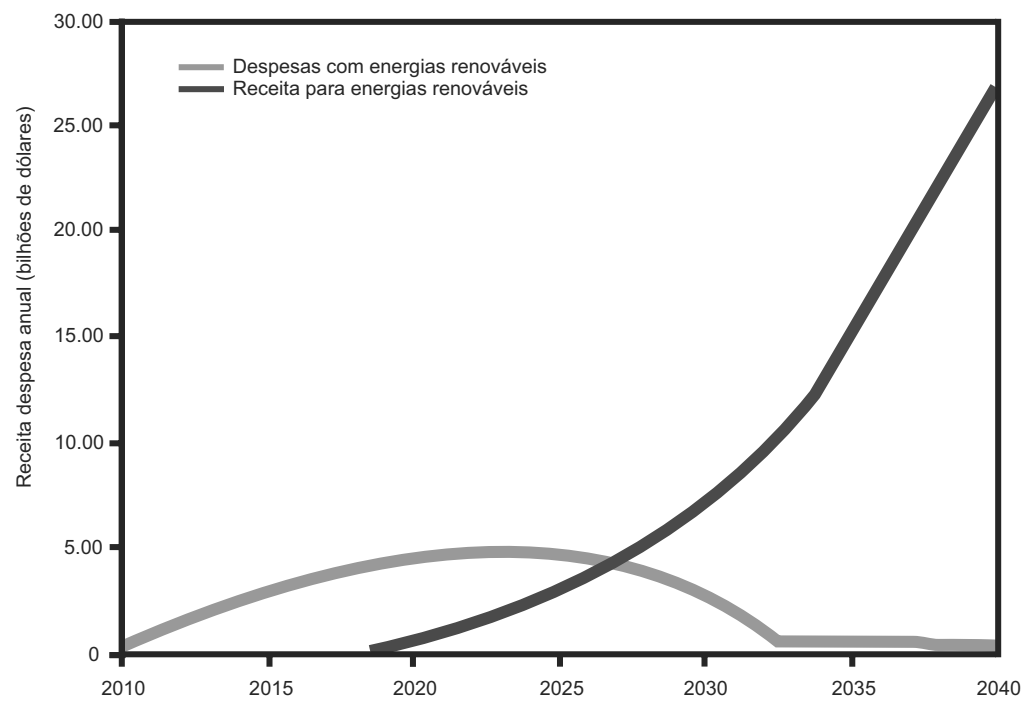


Desenvolvimento Econômico e Social do Brasil (BNDES). Por exemplo, o KfW e o BNDES vêm cooperando em uma série de acordos desde maio de 2008 , voltados para energia e investimentos de tecnologia limpa (por ex. investimento de US\$135 milhões em fazendas eólicas em março de 2009; além de investimento de US\$68 milhões em pequenas centrais hidroelétricas em dezembro de 2010). Esses acordos foram complementados por um empréstimo de 500 milhões de euros para o BNDES, concedido pelo European Investment Bank (setor de empréstimos da União Europeia) para projetos de mitigação de mudança climática.

\section{Banco Brasileiro de Desenvolvimento Econômico e Social}

O BNDES por direito próprio está promovendo ativamente investimentos em setores de tecnologia limpa no Brasil - como financiamento para construção de novos dutos de etanol (um empréstimo-ponte de $\mathrm{R} \$ 1.7$ bilhões para um duto ligando as áreas de produção de etanol aos centros metropolitanos de São Paulo e Rio de Janeiro). Ou em projetos de menor escala, como projetos de $\mathrm{R} \$ 34$ milhões para transformar lixo urbano em combustível (RDF: combustível derivado de rejeitos). O maior desses empréstimos nos últimos tempos foi o compromisso do banco de suprir verbas de até Rs\$ 20 bilhões para construção de um Trem de Alta Velocidade entre São Paulo e Rio, aprimorando assim a infraestrutura do país e reduzindo drasticamente as emissões de carbono ligadas a transporte, assim como congestionamentos. ${ }^{16}$

\section{Exemplo Hipotético}

Para ver como podem funcionar financiamentos inovadores para iniciativas de desenvolvimento verde em larga escala, vejamos um exemplo hipotético no Brasil. Digamos que o BNDES emita um "climate bond" de US\$1 bilhão em mercados de títulos de Nova York e Tóquio, com garantia do governo brasileiro. Ao discutir garantias ordinárias governamentais, como garantias do tesouro, o governo se compromete a reembolsar os investidores por meio de suas arrecadações, geralmente impostas. No caso de um "climate bond", seria necessário um tipo diferente de comprometimento, tanto em relação às fontes de receita (por ex. de receitas cumulativas dos fornecedores de energias renováveis) quanto em relação a ações específicas para mitigar as mudanças climáticas ou dar suporte à adequação a mudanças climáticas previstas (por ex.'ring-fencing" os fundos gerados por atividades relacionadas ao clima).

Esses compromissos teriam de ser claramente visíveis para os investidores e respaldados por garantias e auditorias, para assegurar que os fundos fossem realmente gastos conforme anunciados. Afinal de contas, os investidores estão interessados em um retorno correspondente ao risco que estão dispostos a correr. Ring-fencing os investimentos a serem realizados com verbas provenientes dos títulos daria aos investidores alguma certeza de que os fundos não seriam gastos em projetos 
irrelevantes, que poderiam não atender às metas ambientais e à percepção de risco dos investidores. Uma forma seria o governo brasileiro incorporar um acordo ou um compromisso contratual de um provedor de energia no Brasil ao Prospectus expedido com relação ao título. Digamos que haja um acordo com a Petrobras, empresa estatal de petróleo e biocombustíveis, para elevar a proporção do seu mix de biocombustíveis em, digamos, 5\% por um período de dez anos. Esse acordo exigiria que a Petrobras fizesse os necessários investimentos em termos de crescimento, processamento e compra de biocombustíveis além de quaisquer outros investimentos em questão. Com esse acordo a Petrobras tornaria o "climate bond", emitido pelo BNDES com o respaldo do governo brasileiro, digno de credibilidade para investidores dos mercados de títulos de Nova York e Tóquio. E os fundos levantados pelo título poderiam ser alocados pelo BNDES para empresas brasileiras da cadeia de valor de biocombustíveis, permitindo que essas empresas fizessem os investimentos necessários, e também a própria Petrobras. Esses fundos seriam disponibilizados pelo BNDES em um nível de juros pelo menos comparável àqueles disponíveis em outros investimentos de desenvolvimento, provavelmente com uma taxa melhor devido aos efeitos de agregação provenientes do próprio título. A taxa de juros do repasse deveria ser relativa ao custo do empréstimo internacional, incluindo taxa de risco da operação, opções para cobrir esses riscos, e outros fatores. Assim, esses projetos individuais ligados à elevação do nível de biocombustíveis no mix nacional de combustíveis, que seriam inviáveis a altas taxas de juros, se tornariam exequíveis quando financiados com as verbas do título.

Como uma alternativa, o "climate bond" emitido pelo BNDES com garantia do governo brasileiro poderia ser respaldado por um acordo com a distribuidora nacional de eletricidade, Eletrobras, onde mais uma vez poderia haver um compromisso de reforçar o grid de energia elétrica nacional com outros suprimentos elétricos de recursos renováveis, inclusive energia hídrica, eólica e solar. (Reconhecemos que o Brasil já conta com recursos hidroelétricos substanciais utilizados para gerar energia elétrica.) Novamente esses compromissos da Eletrobras poderiam ser incorporados ao Prospectus através do qual o título é emitido. Novamente, a Eletrobras teria de fazer investimentos em recursos de energia renovável para atender a esses compromissos, e os fundos levantados através do título poderiam ser utilizados precisamente para fazer esses investimentos, canalizados para a Eletrobras e para empresas de energia renovável e fornecedores dos equipamentos pelo BNDES. Mais uma vez isso proveria um meio de superar deseconomias de escala, permitindo que pequenos projetos deslanchassem (através de agregamento), que poderiam ser frustrados se buscassem individualmente, digamos, empréstimos bancários ordinários ou private equity.

Portanto, a estratégia oferece um meio de driblar a desvantagem do custo inicial de tecnologias verdes e estratégias verdes em geral. $E$ à medida que tais projetos são desenvolvidos, começam a gerar retornos absolutamente desproporcionais aos valores investidos. Os novos setores formam o núcleo das novas indústrias, e 
oferecem oportunidades de empreendimento que se multiplicam à medida que os setores se expandem e ligam-se uns aos outros. Isso é o quê vem sendo aptamente descrito como 'reação em cadeia' - e depende do quê os teóricos de desenvolvimento chamam de "causalidade circular e cumulativo". Essa expressão caiu em desuso nos círculos de desenvolvimento, mas voltará a ser usada porque capta perfeitamente o espírito da expansão de uma economia verde dentro do cerne da antiga economia de combustível fóssil.

\section{Desenvolvimento verde como um "Grande Impulso": Barreiras à implementação e como estão sendo superadas}

Podemos chamar a estratégia do Desenvolvimento Verde de um 'Grande Impulso', segundo a terminologia de Rosenstein-Rodan (1943) e outros economistas desenvolvimentistas, na década de 1940 e 1950, que conceberam o desenvolvimento não como um processo incremental, que não daria certo por falta de massa crítica e interconexões, mas como um grande impulso financiado por um banco estatal através de diversos setores industriais simultaneamente. Isso teria o efeito de criar uma massa crítica e construir interconexões setoriais que estimulariam o crescimento. ${ }^{17}$

O conceito do "Grande Impulso" foi abandonado no museu de conceitos antes interessantes mas hoje obsoletos. Não é mais aplicado pelo Banco Mundial nem por outras agências de desenvolvimento - embora seja tão válido hoje como quando foi formulado pela primeira vez. É aplicado (na prática, mas não explicitamente) pela China com grande sucesso. Eu proponho a utilização desse conceito no contexto mais premente de hoje, ou seja, na construção de um setor de energia verde como uma solução para (1) ambições de desenvolvimento e (2) resolução de questões de aquecimento global.

É um conceito desenvolvimentista poderoso, porque se baseia no desenvolvimento estratégico de ligações inter-empresariais que criam o máximo valor agregado para cada dólar investido na economia. Sem ligações não há retornos crescentes, e a economia só pode ter um crescimento "extensivo" com base na crescente exploração de recursos naturais. Mas com ligações entre empresas, repetidas e multiplicadas pelos setores, a economia é capaz de gerar crescentes retornos - o quê o heterodoxo economista de Cambridge, Nicholas Kaldor (1970), chamou de 'reação em cadeia' baseada em "causalidade circular e cumulativa".18 Essa ligação capacita as empresas a alavancar novas técnicas e ideias entre si, e a repetida aplicação desse processo gera um maior conhecimento, ou aprendizado.

No século vinte e um, é provável que o Grande Impulso apresente criação de "ilhas" de expansão permanente nos negócios de economia verde, gerando crescentes retornos (receitas) provenientes dessas ligações entre si que propagam e crescem como uma reação em cadeia - não pelas ligações com a economia convencional de combustível fóssil. Elas formarão estruturas supra-empresas, como aglomerados e 
parques ecoindustriais 'virtuais' com foco concentrado nos seus esforços, permitindo que os empresários de Fontes de Energia Renováveis tenham oportunidade de lucros, que de outra forma não conseguiriam ter.

É um conceito poderoso para resolver problemas de aquecimento global porque a transição para renováveis é o único meio prático, exeqüível e efetivo para reduzir emissões de carbono. Mas a transição tem de ser efetuada em escala, e em velocidade suficiente para conter as emissões desastrosas para o caminho do "business as usual" Porém a maioria das projeções existentes de emissões de carbono feitas por agência governamentais, como a IEA e OECD, dizem respeito a meras reduções numéricas de concentrações de carbono em certa data - sinais meramente retóricos não ligados a nenhuma transição real de energia.

O desenvolvimento verde promete na verdade produzir um tipo diferente de capitalismo industrial, e parece mais praticável e provável que o caminho hoje discutido do 'business as usual,' de combustível fóssil -- que implicou um século de terríveis guerras, nações lutando pelo último vestígio de petróleo, carvão e gás e outros recursos. O que é mais realista, um mundo preso ao seu passado movido a combustível fóssil e países lutando entre si até a morte em razão dos últimos suprimentos minguados, ou um mundo que aprendeu a usar os abundantes suprimentos de energia provenientes de recursos renováveis, e recircular seus recursos através de uma Economia Circular, criando assim condições para uma tolerância internacional? Uma guerra terrível e brutal de todos contra todos em um futuro de combustível fóssil será realmente a única opção para nossa civilização industrial? Ou a alternativa de energias renováveis e sistemas de economia circular será realmente mais realista?

Os novos caminhos também constituem uma nova agenda de desenvolvimento, oferecendo aos países, que aspiram a elevar seus padrões de vida através da industrialização e engajamento na economia global, um novo começo e novas possibilidades de construir indústria de ER orientadas para exportação. A agenda do desenvolvimento tradicional, promovida pelo Banco Mundial e muitas outras agências, sempre assumiu implicitamente que as indústrias seriam construídas com base nos combustíveis fósseis - copiando o caminho do Ocidente. Mas a energia renovável e a alternativa eco-industrial realmente oferecem a um país que está procurando estabelecer novas indústrias um caminho mais promissor, explorando seus próprios recursos abundantes e oferecendo empregos e oportunidades industriais que de outra forma não existiriam. ${ }^{19}$

A emergência de uma economia verde promete ser sistêmica, suas partes interagindo umas com as outras, e exigirá um novo "economista verde" menos obcecado com o PIB e custos de transição. As correntes predominantes de economia não têm nada a ensinar sobre a emergência da economia verde porque é expressa em termos de processos de fluxo linear e não circular; porque é focalizada no equilíbrio estatístico (mesmo em modelos dinâmicos) e não em estados evolucionários estáveis que podem ser atingidos através de iniciativas ecoindustriais; e porque procura 
justificar a distribuição de renda através de crescimento econômico e não através de medidas diretas, como compras e regulamentações governamentais de mercado. Os BICs estão inventando não só uma nova economia verde como também uma nova ciência econômica verde.

\section{Há uma nova onda longa em se formando - pelos investimentos dirigidos em energias renováveis?}

A transição atual para economia circular e iniciativas de energia renovável pode ser situada em um contexto histórico maior, como a mais recente de uma série de convulsões industriais e transformações. Existe uma nova "onda longa" se formando, com os investimentos dirigidos no setor de energia renovável? O relevante aqui é o trabalho de Andrey Korotayev. Em resultado à análise espectral de ondas longas conduzida por seu colaborador Sergey Tsirel, Korotayev analisa a situação atual (a partir de 2011) como se movendo em uma de duas diferentes direções. O background para essa análise é suprido pela análise espectral das terceira, quarta e quinta ondas longas durante 140 anos - de 1870 a 2010 - conforme mostra a Fig. 7 abaixo.

Os acadêmicos russos interpretam sua reconstrução de ondas longas através da análise espectral, revelando um padrão surpreendentemente consistente de onda longa, com um claro encurtamento do período de onda mais recente. O período atual, semelhante ao pico da quinta onda $\mathrm{K}$, pode na verdade ser esse - e a crise financeira global de 2008-09 seria entendida por essa leitura como o sinal da recessão. Mas os autores também oferecem uma alternativa e uma leitura muito intrigante - ou seja, o período atual pode ser interpretado como uma depressão temporária entre os dois picos de ascensão. Por extrapolação, eles prevêem que essa ascensão temporária

Fig. 7. Padrão de onda K revelada por análise espectral, 1870-2010

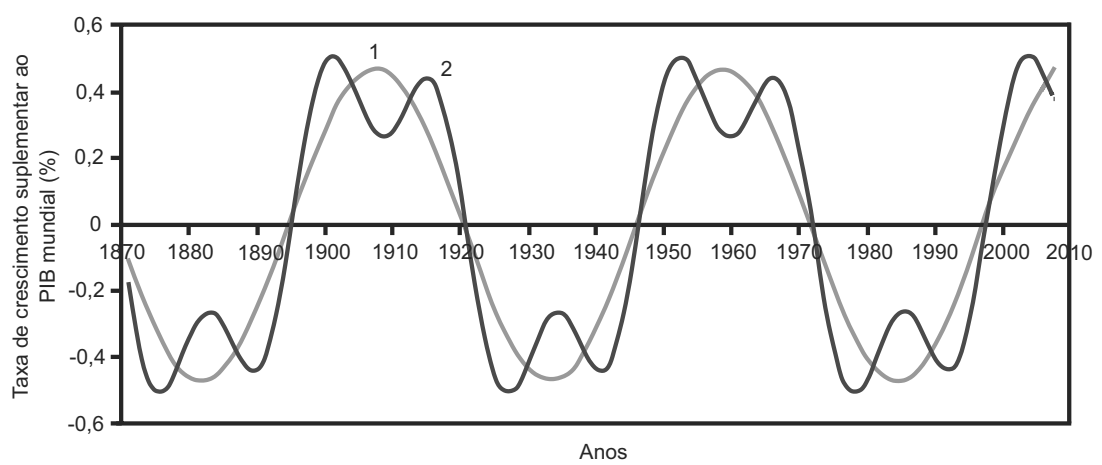

Fonte: Korotayev and Tsirel (2010), Fig. 3-A, mostra o primeiro harmônico (onda 1) e a soma do primeiro e terceiro harmônicos (curva 2) com os valores da Primeira Guerra Mundial e do intervalo entre as guerras reposicionados por média geométrica. 
poderá ocorrer em torno de 2011-2012 (i.e. agora) e alcançar seu máximo em 20182020. A fonte dessa ascensão temporária não é explicada no paper russo. Eles não levam em conta o papel de comunicações e tecnologia da informação, que se considera terem exaurido suas reservas de crescimento rápido. Um fator que apontam é a aceleração da convergência (do Oriente ao Ocidente) através da "aceleração da difusão das altas tecnologias existentes para os países populosos da periferia do Sistema Mundial" - entre os quais os BICs seriam vistos como os principais exemplares, e onde as tecnologias verdes teriam de ser identificadas como opções principais. Embora expressando a cautela apropriada, na realidade essa parece ser a opção implícita dos autores para a subida secundária em 2011-12. Contudo, há também forte evidência de que a interpretação mais óbvia -- de que o PIB mundial acabou de alcançar seu pico de onda $\mathrm{K}$ - é também plausível, particularmente se o mundo cair em uma "recessão dupla" (double-dip recession) em 2011-12. Os autores concluem: "No momento não parece possível decidir finalmente quais das duas interpretações é verdadeira." 20

Essa é certamente a mais forte justificativa possível para governos gastarem o que que for necessário para evitar uma recessão dupla, abrindo para os BICs a possibilidade de criarem uma "curta ascensão" a partir de investimentos em tecnologias renováveis e de baixa emissão de carbono. Não é hora de assumir-se uma postura desinteressada e declarar que "o mercado" irá corrigir isso. É uma coisa que os países terão de corrigir por eles mesmos.

\section{Desenvolvimento verde como o caminho a seguir}

O processo de industrialização tirou perto de 1 bilhão de pessoas na Europa Ocidental, América do Norte e Japão da "armadilha malthusiana' e levou-as a uma trajetória de aumento de renda per capita (Pomeranz 2000). Isso criou uma Grande Divergência entre o Ocidente e o resto do mundo, por conta das extremas disparidades de riqueza, renda e poder que caracterizaram o mundo moderno. No século vinte, apesar dos sérios esforços de industrialização em várias partes do mundo, só no leste da Ásia foi atingida a "convergência". No século vinte e um esses esforços espalharamse pela China, Índia e Brasil, e uma Grande Convergência está a caminho, revertendo as trajetórias dos últimos 200 anos. Contudo, se por volta de 6 bilhões de pessoas passarem a ter nível médio de renda até 2050 (como previsto por economistas como Michael Spence, 2011) o modelo de industrialização terá de ser sextuplicado. Mas isso poderá ser feito sem 'cozinhar' o planeta pela queima de combustível fóssil ou sem "devorar" o planeta pelo uso excessivo de recursos naturais? Essas questões fundamentais não podem ser evitadas, devem ser enfrentadas por qualquer avaliação de prováveis tendências industriais no século vinte e um e por qualquer proposta para estratégia de desenvolvimento.

São os BICs (e particularmente a China) que parecem já ter encontrado tais respostas e estarem desenvolvendo um modelo industrial que realmente "se 
ajustará", a fim de abranger bilhões de novas pessoas que aspiram a um melhor padrão de vida. Parece ser entendido dentro da liderança chinesa que o caminho à industrialização alimentado por combustíveis fósseis levará a uma tensão geopolítica sem fim - guerras por recursos naturais e mais destruição do meio ambiente na China e em outros países. Portanto, há que ser encontrado um caminho alternativo, e esse caminho está sendo desenvolvido através de uma série de inovações de ampla visão no setor de energia (recursos renováveis e uma rede inteligente de distribuição de energia), no setor de recursos e commodities (economia circular) e no setor financeiro (bancos de investimento verde). Embora a China esteja expandindo seu sistema de energia de combustível fóssil em uma velocidade sem precedente, ao mesmo tempo vem expandindo sistemas alternativos de ERI --- dobrando sua capacidade de energia eólica anualmente desde 2005 e ampliando seus sistemas de energia solar fotovoltaica no período atual do $12^{\circ}$ Plano Quinquenal, além de investir em um grid elétrico robusto e inteligente que possa coletar e distribuir energia de diversas fontes renováveis flutuantes. Ao mesmo tempo tem perseguido ativamente um modelo de Energia Circular, baseado em ligações ecoindustriais entre empresas, que se afastam da Economia Linear convencional.

Assim como a China vem tendo sucesso na construção dessa nova trajetória, pode-se esperar que a Índia também venha a ter, talvez com uma década de atraso, pois esse tem sido o padrão em outras importantes iniciativas industriais, tais como o estabelecimento de clusters industriais e Zonas Econômicas Especiais. Se a Índia seguir uma trajetória com um claro foco em renováveis, como vem dando sinal de estar seguindo, também estará seguindo um caminho de desenvolvimento exequível. O Brasil deu igualmente claros passos nessa direção, particularmente na produção de bionergia, onde tem claras vantagens comparativas. Essa é agora uma agenda comum de desenvolvimento dos BICs. Esses países estão construindo novas indústrias"verdes" por meio de "inovação rápida" - a estratégia aperfeiçoada pelos "tigres asiáticos" no século vinte para, em tempo, alcançar o estado da arte nas indústrias de eletrônica e de tecnologia da informação. Essas mesmas estratégias de inovação rápida estão sendo implantadas no século vinte e um para acelerar a difusão de tecnologias de baixa emissão de carbono e de uso eficiente de recursos a fim de desenvolver um caminho de industrialização que não prejudique a terra. ${ }^{21}$

Neste paper argumentei que a China foi quem mudou o jogo - elevando o perfil de desenvolvimento verde de uma curiosidade (de interesse marginal) a uma nova indústria competitiva capaz de prover uma economia gigantesca ao longo de uma trajetória de desenvolvimento que "se ajustará" às dimensões necessárias, sem prejudicar a terra. O modelo de desenvolvimento verde que a China está arquitetando, e que já vem sendo copiado sob certos aspectos pelo Brasil e pela Índia, e no mundo desenvolvido pela Alemanha, oferece a maior esperança de desenvolvimento sustentável para a próxima onda de países que seguem os BICs, inclusive os países em desenvolvimento da África, 


\section{América Latina, Ásia e Oriente Médio}

Mas a China, a pragmática superpotência, está também desenvolvendo seu sistema de energia alimentada a carvão com a mesma velocidade com que desenvolve o sistema de renováveis. Isso levaria a uma avaliação pessimista, não fosse o fato de as indústrias verdes serem autossustentáveis e crescerem através da logística da dinâmica industrial (curva S) de forma circular e cumulativa - enquanto as pressões dos recursos e aumento de custos indicam um final próximo das indústrias alimentadas por combustíveis fósseis. É claro que não há garantia de que a China, os BICs e outros países em desenvolvimento possam correr atrás de tais modelos de desenvolvimento rápido o suficiente para manter as emissões de carbono e a espoliação de recursos naturais dentro de limites aceitáveis.

Em minha opinião, o modelo de desenvolvimento verde é uma entidade emergente, cujo caráter é melhor percebido nas estratégias e iniciativas que se dão na China, onde fortes instituições estatais com capacidade de tomar decisões e agir de forma decisiva, vêm demonstrando ser um poderoso fator. Esse modelo é'emergente' no sentido de que suas linhas gerais estão se tornando claras, mas sua implementação real é toldada por estabelecimento de contra-políticas que favorecem os combustíveis fósseis e a energia nuclear, tanto por interesses ocultos quanto por novas iniciativas impostas por esses interesses.

Embora a comunidade internacional venha debatendo sobre aquecimento global, e os acadêmicos e ativistas venham assinando tratados internacionais mais rigorosos como uma forma de lidar com o problema (Kyoto etc), a China e os BICs parecem ser motivados por considerações bem distintas. No início do século vinte e um, depois que o ingresso da China na OMC foi concretizado, em 2001, a liderança do país já via uma onda de investimentos em atividades manufatureiras para exportação. Essa máquina de manufatura voltada para exportação exigiu uma imensa expansão de energia, e a única energia disponível era proveniente de combustíveis fósseis - inicialmente carvão. Então o Partido Comunista Chinês tomou duras decisões em termos de expansão da energia alimentada por carvão e expansão e racionalização da indústria de fornecimento de carvão. Mas a expansão industrial também exigia petróleo e gás, e a China já tinha chegado ao limite desses recursos e dependia de expansão para o exterior a fim de sentir-se segura no que diz respeito a petróleo.

Então ocorre o 11 de setembro, com um ataque terrorista no coração de Nova York por nacionalistas sauditas, que teve como resposta a "Guerra ao Terror". Como esses acontecimentos seriam vistos em Pequim? É absolutamente plausível que a liderança do Partido Comunista Chinês tivesse associado mais expansão do seu interesse por petróleo e combustível fóssil ao risco sem fim de Guerra e terror - envolvendo conflitos não só com as nações "aliadas" do Oriente Médio, mas também com os Estados Unidos, e seu apetite aparentemente ilimitado pela "energia" do Oriente Médio (ou seja, petróleo). Nessas circunstâncias, um caminho alternativo de energia com rápido 
estabelecimento de recursos renováveis pareceria justificável e racional. E exatamente isso é o que pode ser observado. Com um atraso de dois anos, os investimentos da China em renováveis, inicialmente energia eólica e energia solar térmica, subiram depois de 2005 em ritmo sem precedente na história da economia. No atual $12^{\circ}$ Plano Quinquenal, espera-se que a capacidade de renováveis se expanda ainda mais e que em torno de 2020 representem 30\% da geração de energia elétrica na China uma enorme mudança em uma enorme máquina industrial. Embora as corporações estatais continuem sendo o alicerce do sistema energético em carvão, petróleo e gás e em geração de energia elétrica, novas corporações privadas estão sendo autorizadas a atuar no setor de ER em geral, na medida em que centenas de empresas entregam-se avidamente aos novos setores de energia eólica, solar fotovoltaica e solar térmica, e também a várias formas de bioenergia e combustíveis alternativos.

Esse é o atributo mais "conveniente" das atuais políticas de energia da China. Significa que seus esforços em "abastecer" a continuada expansão industrial cultivando recursos de RE, que substituirão gradualmente os recursos fósseis, podem ter dois efeitos importantes. Primeiro, está diminuindo o risco de a China entrar em guerras por petróleo e outros recursos industriais com países aliados ou com os Estados Unidos. Essa é justificadamente a meta de toda a estratégia de energia - de enormes benefícios para a China e para o mundo. O segundo efeito 'conveniente' é que a abordagem da China provê o melhor meio de lidar com a ameaça do aquecimento global. Embora o resto do mundo venha discutindo a respeito da imposição de limites a emissões de carbono, através do acordo de Kyoto, hoje esquecido (limites que os próprios Estados Unidos recusaram-se a impor), e embora a China tenha sido vilipendiada por não adotar esses limites, na prática ela vem construindo o setor de Economia Renovável com seriedade como o único meio de reduzir - realmente reduzir - as emissões de carbono. $\mathrm{O}$ mundo terá de esperar alguns anos até as emissões de carbono da China atingirem um platô e começarem a declinar. Mas - a não ser que ocorram catástrofes - isso é seguramente o que deverá ocorrer.

Países avançados já reconhecem o mérito da China ao seguirem sua abordagem de um sério desenvolvimento de indústrias de energia renovável. A Alemanha, como vimos, foi a primeira a declarar, em junho de 2011, depois do desastre de Fukushima no Japão, uma incrível reviravolta ao optar pela redução de sua dependência de energia nuclear (o que retardou durante décadas a opção por energia renovável), e a seguir fez sucessivas declarações sobre seus planos de ampliação de indústrias de energia renovável. Assim, a Alemanha passa de sua já forte promoção de mercados de energia renovável --via sistema de tarifa de feed-in corporificado na Lei de Fontes de Energia Renovável de 2000 e em ocorrências anteriores -- para uma promoção muito mais significativa das próprias indústrias de energia renovável, exatamente como foi feito pela China. Portanto, os sistemas alemães de energia eólica e solar fotovoltaica, e o respaldo da Alemanha aos sistemas de energia solar concentrada (Concentrate Solar Power - CSP) em áreas desérticas do norte da África, (como o ambicioso projeto 
Desertec) prometem tornar-se mais fortes ecompetir realmente com as indústrias chinesas de energia renovável.

Então, um caminho alternativo deve ser encontrado - e está sendo desenvolvido através de uma série de inovações de ampla visão no setor de energia (recursos renováveis e um grid de distribuição inteligente), no setor de recursos e commodities (iniciativas de economia circular), e no setor financeiro (ecofinanças e bancos de investimento verde). Essas inovações ainda são realizadas em escala relativamente pequena, uma vez que a China prossegue com uma estratégia interina de consumo de combustível fóssil, mas que é claramente concebida para reduzir o consumo à medida que o caminho verde entrar na dinâmica industrial.

Já a história dos Estados Unidos é outra. O país está hoje calculando os custos de uma "década perdida" depois das ocorrências do 11 de setembro em 2011. A política externa americana baseou-se no petróleo desde que seus suprimentos internos chegaram ao pico em 1970. Planos cada vez mais ambiciosos para garantir e proteger as linhas de suprimento de petróleo foram formulados na década de 1990 e levados a cabo pela administração Bush de 2000 a 2008. As ocorrências de 11 de setembro fortaleceram a decisão americana de garantir essas linhas de suprimento de petróleo, ocasionando a invasão do Iraque sob pretexto de investigação da existência de "armas de destruição em massa". Mas essa estratégia mostrou ser absolutamente errada -- Osama fugiu para o Afeganistão e instigou as Forças Armadas americanas a entrarem em uma guerra longa e infrutífera (onde não há petróleo); e um levante sunita no Iraque manteve as forças americanas ocupadas, impedindo quaisquer incursões potenciais no Oriente Médio ou na região da Ásia Central, em torno da bacia de petróleo do Mar Cáspio. A potencial invasão do Irã foi renegada pela China, que forjou uma forte aliança com o Irã para garantir seu suprimento de petróleo nesse país - enquanto expandia seu suprimento oriundo de países africanos, como a Namíbia, o Congo e a Nigéria, muito além da esfera de influência dos Estados Unidos. Nesse ínterim o Congresso Americano deu um respaldo fraco e episódico aos recursos renováveis, e recusou-se a acabar com subsídios aos combustíveis fósseis, frustrando esforços de desenvolver significativos esquemas cap and trade para conter emissões de carbono que teriam também fornecido incentivos para recursos renováveis. Durante essa'década perdida'a dependência dos Estados Unidos do petróleo aumentou, enquanto seus grandes competidores industriais no Oriente (China) e no Ocidente (Alemanha) seguem em outra direção, construindo os sistemas de energia renovável e economias circulares que irão estabelecer sua liderança tecnológica e -- para aqueles que seguem seu exemplo -- tornar redundantes as guerras por recursos no século vinte e um. Os 10 elementos do Consenso de Washington deviam realmente ter inserido um $11^{\circ}$ ponto (que está implícito) -- "Seguir um caminho de combustível fóssil". Mas isso hoje está tão desacreditado quanto o próprio Consenso de Washington.

Tais considerações geopolíticas encontram-se na raiz da criação de um modelo de desenvolvimento verde. O novo tipo de modelo industrial que está emergindo, e sendo impulsionado pela China e BICs e também pela Alemanha, pode oferecer 
perspectivas realistas de conter e verdadeiramente diminuir emissões de carbono, ao mesmo tempo reduzindo o consumo de recursos (minério de ferro, cimento alumínio etc) via iniciativas e políticas de economia circular Esse modelo emergente está sendo conduzido, não por declarações teóricas estilo Kioto em termos de reduções programadas de emissões de carbono (declarações inúteis na prática), nem por afirmações de preocupação com o futuro da civilização industrial. Ao contrário, está sendo conduzido por interesses nacionais e numa visão de longo prazo de iniciativas estatais e de dinâmicas competitivas que compõem um sistema industrial sustentável.

Porém isso não é uma grande novidade. Conforme mostram os registros, o condutor-chave de mudança na área de energia foi quase sempre o poder territorialmente concentrado dos países, motivado por um forte senso de interesse nacional. Observem a fantástica mudança dos exércitos alimentados a carvão e puxados a cavalo que combateram na Primeira Guerra Mundial para os exércitos motorizados e já alimentados a petróleo que lutaram na Segunda Guerra Mundial. Os Estados Unidos emergiram como claros vencedores porque dominavam o paradigma industrial com base no petróleo, usando seu poder do estado para realizar a mudança. Da mesma forma, no século dezenove o estado americano conduziu a mudança de canais e carruagens para ferrovias como um modo industrial de transporte, estabelecendo padrões, concessões de terras e benefícios fiscais que atraíram empreendimentos para o novo setor. Podemos esperar que um processo semelhante ocorra no século vinte e um, à medida que países fortes estabeleçam a agenda para a nova economia verde e sistema industrial, encorajando e estimulando outros a seguirem seu caminho. É um modelo poderoso de transição conduzido pelo estado, que a Índia e o Brasil procurarão copiar mesmo mantendo suas características democráticas e capitalistas.

É claro que o sucesso nesses vastos "experimentos não controlados" está longe de ser garantido. As forças da inércia industrial, do 'lock-in de carbono' podem muito bem prevalecer e obstruir mais iniciativas verdes. A China poderá sofrer um enorme revés econômico a certa altura e permitir que uma liderança de menos visão assuma o controle, refreando os investimentos em recursos renováveis e na economia circular. Cenários e processos semelhantes poderão ser vistos nos BICs e também na Alemanha e no Japão, levando esses países a disputa direta com os Estados Unidos por combustíveis fósseis, arrastando-os para incontroláveis guerras por recursos no Golfo Pérsico, na bacia do Mar Cáspio e em outras regiões ricas em combustível fóssil. O "cozimento" do planeta através do aquecimento global poderá fugir ao controle e mergulhar nossa civilização industrial em uma série de desastres ambientais, guerras e revoluções que matarão os 'green shoots' cultivados com tanta dificuldade. Tudo isso é possível. Mas conforme diz Paul Gilding (2011), “Nós [os cidadãos do Planeta Terra] podemos ser lentos, mas não somos imbecis". ${ }^{22}$ Seria um ato monumental de loucura permitir que interesses específicos bloqueassem a atual transição para uma economia e sistema industrial mais verdes. Se a transição se fará a tempo, é uma questão que não que não pode ser prevista com qualquer certeza. 


\section{Notas}

' Ver Spence (2011), e também seu comentário sobre Project Syndicate, 'Asia's new growth model' (June 1 2011), encontrado em: http://www.project-syndicate.org/commentary/spence23/English. Spence data a industrialização a partir de 1750, e considera seus dois primeiros séculos até 1950 dominados pelos países industriais desenvolvidos do Ocidente, mas o terceiro século, de 1950 em diante, e particularmente no período de 2000 em diante, sendo a era de difusão e disseminação do sistema pelo mundo inteiro.

${ }^{2}$ Ver 'In the grip of a great convergence', de Martin Wolf, Financial Times, Jan 4 2011. A "grande convergência" (4) Convergência asiática do PIB per capita

${ }^{3}$ Ver o paper que deu início a essa corrente, de Antonio Barros de Castro (2008). Subsequentemente, "O lugar do Brasil em um mundo sinocêntrico"foi o título de uma conferência realizada no Rio em 2010, onde eu tive o privilégio de fazer uma apresentação.

${ }^{4}$ Este segundo grupo englobava 31empresas dentre 11 indústrias-chaves; 17 áreas/empreendimentos engajados em quatro atividades-chave; 20 parques industriais; e 17 províncias e cidades foram listados. Ver Mathews and Tan 2011 com respeito a elaboração, e Mathews, Tang and Tan 2011 com respeito à argumentação de que a China está utilizando iniciativas de Economia Circular como nova fonte de competitividade.

${ }^{5}$ Uma breve experiência em contabilidade do"PIB Verde"foi realizada pela Agência de Proteção Ambiental do governo da China, com o respaldo de economistas como Hu Angang - mas no final foi descontinuada. Ver Li and Lang 2010 para um relato. As idéias de Hu são coerentes com as da "modernização ecológica", que foi um conceito popular na China (ver Mol 2002 sobre elaboração).

${ }^{6}$ Ver o relatório da Corporate and Social Responsibility do Agricultural Bank of China, disponível em: http://www.abchina.com/en/about-us/csr-report/

${ }^{7} \mathrm{O}$ Brasil tem significativas vantagens na produção de bioetanol e biodiesel devido à estabilidade das safras tropicais, particularmente a cana de açúcar. Ver Goldemberg et al 2008 sobre uma visão geral da capacidade do Brasil de produzir bioenergia em um ritmo sustentável, e Macedo et al 2008 sobre uma análise do ganho de energia (Energia Recuperada por unidade de energia investida) no setor de etanol do Brasil.

${ }^{8}$ Ver "Brazil's Wind Power Auction Spurs More Clean Energy Development", de Nelson Hubner, Renewable Energy World.com, 29 dez. 2009, disponível em: available at: http://www.renewableenergyworld.com/ rea/news/article/2009/12/brazils-wind-power-auction-spurs-more-clean-energy-development

${ }^{9}$ Ver'Brazilian wind power gets a boost',de Robert Walzer,no New York Times, Nov 9 2009, disponível em: http://green.blogs.nytimes.com/2009/11/09/brazilian-wind-power-gets-a-boost/

${ }^{10}$ Brasil tem um grupo florescente de acadêmicos ligados a energia, muitos dos quais encontram-se na COPPE, na Universidade Federal do Rio de Janeiro. Ver Rosa et al (2004) sobre uma intervenção em apoio à posição do Brasil nas negociações climáticas internacionais, e Lins et al (2011) sobre uma recente intervenção com relação a uma maior dependência do Brasil em biomassa como fonte de calor e energia. Um artigo especial sobre'Green economy: Challenges and opportunities'foi publicado pelo Conservation International Brazil, in Política Ambiental, No. 8, June 2011, disponível em: http://www.uncsd2012.org/ rio20/content/documents/politica_ambiental_08_ingles.pdf. Em particular, Frischtak (2011) argumenta que a antiga "escolha" entre maior crescimento ou maior conservação está hoje obsoleta, e que o Brasil é o pioneiro de uma nova estratégia verde que atinge ambas as metas.

${ }^{11}$ Uma importante conferência sobre CSP foi realizada em Nova Delhi em abril de April 2011 (ver http://www.csptoday.com/india/). Versões de baixa tecnologia de Energia Solar Concentrada, próprias para uma ampla difusão, já se encontram em grande uso na Índia, tais como a'cozinha solar' ou 'o bowl solar (ver http://www.auroville.org/research/ren_energy/solar_bowl.htm).

12 Sobre a adoção na Índia da inovação institucional da China de Zonas Econômicas Especiais, como a estrutura dentro da qual grupos podem florescer, incluindo grupos de produtores de equipamento de energia renovável, ver o trabalho de Aradhna Aggarwal 2010. Ela apresenta grande parte desse trabalho no seu livro a ser publicado, Social and Economic Impacto f SEZs in India (Oxford University Press 2012)

${ }^{13} \mathrm{Hu}$ fez sua argumentação em dois papers de muita influência, explicando por que o desenvolvimento verde foi "uma escolha inevitável para a China" (Hu 2006a; -b). Depois publicou um livro pela Brookings Institution sobre China in 2020: A Different Kind of Superpower (Hu 2011), que também dedica um capítulo ao modelo de Desenvolvimento Verde. Hu foi um participante ativo da preparação dos sucessivos Planos Quinquenais para a China em tom de desenvolvimento verde, embora não tivesse tanto sucesso ao tentar convencer os administradores regionais do país a seguir uma trajetória de "PIB' Verde. Uma argumentação sobre a alternativa ao "modelo asiático de crescimento" é apresentada por Nair 


\begin{abstract}
2011. O United Nations Environment Program (UNEP) mostra-se hoje fortemente a favor de um modelo de Desenvolvimento Verde (UNEP 2011).

${ }^{14}$ Eu próprio venho escrevendo sobre esses temas há vários anos. Ver Mathews 2007a; -b; 2008; 2009; e 2011; e também Mathews and Kidney 2010 sobre "climate bonds" como meio de financiar a transição; Mathews and Tan 2011 sobre iniciativas de ecossistema na China's; e Mathews, Tang and Tan 2011 sobre economia Circular na China, para amostras representativas. Gostaria agora de fazer uma elaboração sobre o modelo "Pequim-Seul- Tóquio" proposto por Keun Lee da Coreia (Lee and Mathews 2010) também em termos de um modelo de Desenvolvimento Verde.

${ }^{15}$ Essa não é uma representação do 'vale da morte' referida nos estudos de inovação. Lá, a falha do financiamento que leva uma invenção à exploração comercial é o quê preocupa. Na Fig. 6, em contraste, é o "gap" entre custos iniciais para introduzir uma nova tecnologia (nova para o país, mas não para o mundo) e as esperadas receitas, que interessam.

${ }^{16}$ Para esses projetos, ver o website do BNDES e press releases anunciando tais projetos: http://www. BNDES.gov.br/SiteBNDES/BNDES/BNDES_en/

17 Sobre o conceito do "Grande Impulso", ver Rosenstein-Rodan (1943) e Nurkse (1953) como seus principais apresentadores. O conceito, em resumo, é que o desenvolvimento pode falhar em função de pequenas escalas quando setores se desenvolvem individualmente - mas se os desenvolvimentos ocorrerem de forma mais ou menos simultânea, geram interligações trans-setoriais que proporcionam escala suficiente. Houve tentativas ocasionais de formalizar a idéia. Estou sugerindo que o "Grande Impulso" deva ser resgatado de suas associações 'desenvolvimentistas' e tornado central para as estratégias verdes de industrialização.

18 O conceito de Causalidade Circular e Cumulativa foi introduzido por Kaldor (1970) e inspirado por Myrdal (1957). Enfraqueceu na literatura de economia, e merece ser ressuscitado pelo modelo de Desenvolvimento Verde, onde é especialmente aplicável

${ }^{19}$ Essa é uma nova agenda de desenvolvimento já sendo trabalhada por bancos de desenvolvimento nacionais e regionais, como o Asian Development Bank, o BNDES do Brasil, o Inter-American Development Bank - e de certa forma o European Investment Bank.

${ }^{20}$ Ver Korotayev and Tsirel (2010): 19-21

${ }^{21}$ Eu discuti essa estratégia de 'inovação rápida' com relação ao rápido desenvolvimento da indústria solar fotovoltaica de Taiwan com meus colegas Mei-Chi Hu e Ching-Yan Wu (Mathews, Hu and Wu 2011).

22 Paul Gilding, The Great Disruption (2011)
\end{abstract}

\title{
Referências
}

AGGARWAL, A. 2010. Economic impacts of SEZs: Theoretical approaches and analysis of newly notified SEZs in India. Working paper, available from: http://mpra.ub.unimuenchen.de/20902/

CASTRO, A. Barros de 2008. 'From semi-stagnation to growth in a sinocentric world', Revista de Economia Politica 28 (1): 3-27.

FRISCHTAK, C.R. 2011. Brazil and the green economy: Foundations and strategy for transition, Política Ambiental, 8: 96-107.

GILDING, P. 2011. The Great Disruption, Bloomsbury Publishing, London 2011.

GOLDEMBERG, J., COELHO, S.T. and GUARDABASSI 2008. The sustainability of ethanol production from sugarcane, Energy Policy, 36: 2086-2097.

HARDIN, G. 1968. The tragedy of the commons, Science, 162: 1243-1248.

HU, A. 2006a. Green development: The inevitable choice for China (Part 1), China Dialogue, available at: http://www.chinadialogue.net/article/show/single/en/134

HU, A. 2006b. Green development: The inevitable choice for China (Part 2), China Dialogue, available at: http://www.chinadialogue.net/article/show/single/en/135-Green-developmentthe inevitable-choice-for-China-part-two-

HU, A. 2011. China in 2020: A New Type of Superpower. Washington, DC: Brookings Institution. 
KALDOR, N. 1970. The case for regional policies, Scottish Journal of Political Economy, 17: 337-348.

KOROTAYEV, A.V. and TSIREL, S.V. 2010. A spectral analysis of world GDP dynamics: Kondratieff waves, Kuznets swings, Juglar and Kitchin cycles in global economic development, and the 2008-2009 economic crisis, Structure and Dynamics, 4 (1), available at permalink: http://128.48.120.222/uc/item/9jv108xp

LEE, K. and MATHEWS, J.A. 2010. From the Washington Consensus to the BeST Consensus for world development, Asian Pacific Economic Literature, 24 (1): 86-103.

LI, V. and LANG, G. 2010. China's "Green GDP" experiment and the struggle for ecological modernisation, Journal of Contemporary Asia, 40 (1): 44-62.

LINS, M.E., OLIVEIRA, L.B., DA SILVA, A.C.M., ROSA, L.P. AND PEREIRA JR, A.O. 2011. Performance assessment of alternative energy resources in Brazilian power sector using Data Envelopment Analysis, Renewable and Sustainable Energy Reviews, (in press).

MACEDO, I.C., SEABRA, J.E.A. and SILVA, J.E.A.R. 2008. Greenhouse gases emissions in the production and use of ethanol from sugarcane in Brazil: The 2005/2006 averages and a prediction for 2020, Biomass and Bioenergy, 32 (7): 582-595.

MATHEWS, J.A. 2007a. Can renewable energies be turned to a source of advantage by developing countries? Revue de l'Energie, No. 576 (Mar-Apr 2007): 96-105.

MATHEWS, J.A. 2007b. Latecomer strategies for catching-up: The cases of renewable energies and the LED programme, International Journal of Technological Learning, Innovation and Development, 1 (1): 34-42.

MATHEWS, J.A. 2008. Energizing industrial development, Transnational Corporations, 17 (3): 59-84.

MATHEWS, J.A. 2009. China, India and Brazil:Tiger Technologies, Dragon Multinationals and the Building of National Systems of Economic Learning, Asian Business and Management, 8 (1): 5-32.

MATHEWS, J.A. 2011a. Naturalizing capitalism: The next Great Transformation, Futures, 43: 868-879.

MATHEWS, J.A. 2011 b. China's energy industrial revolution, I'Industria, 32 (2): 309-328.

MATHEWS, J.A. and KIDNEY, S. 2010. Climate bonds: Mobilizing private financing for carbon management, Carbon Management, 1 (1): 9-13.

MATHEWS, J.A. and TAN, H. 2011. Progress towards a Circular Economy in China: Drivers (and inhibitors) of eco-industrial initiative, Journal of Industrial Ecology: 15 (3): 435-457.

MATHEWS, J.A., HU, M.-C. AND WU, C.-W. 2011. Fast-follower industrial dynamics: The case of Taiwan's Solar PV industry, Industry and Innovation, 18 (2): 177-202.

MATHEWS, J.A., TANG, Y. and TAN, H. 2011. China's move to a Circular Economy as a development strategy, Asian Business \& Management, (in press).

MOL, A.P.J. 2002. Ecological modernization and the global economy, Global Environmental Politics, 2 (2): 92-115.

MYRDAL, G. 1957. Economic Theory and Under-Developed Regions. London: Duckworth. Nair, C. 2011. Consumptionomics: Asia's Role in Reshaping Capitalism and Saving the Planet, Infinite Ideas, Oxford.

NURKSE, R. 1953. Problems of Capital Formation in Underdeveloped Countries. Oxford: Basil Blackwell. 
POLANYI, K. 1944 (1957; 2001). The Great Transformation: The Political and Economic Origins of Our Time (Foreword Joseph E. Stiglitz; Introduction Fred Block). Boston, MA: Beacon Press.

POMERANZ, K. 2000. The Great Divergence: China, Europe and the Making of the Modern World Economy. Princeton, NJ: Princeton University Press.

ROSA, L.P., RIBEIRO, S.K., MUYLAERT, M.S. and DE CAMPOS, C.P. 2004. Comments on the Brazilian proposal and contributions to global temperature increase with different climate responses - $\mathrm{CO} 2$ emissions due to fossil fuels, $\mathrm{CO} 2$ emissions due to land use changes, Energy Policy, 32: 1499-1510.

ROSENSTEIN-RODAN, P.N. 1943. Problems of industrialisation in Eastern and South-Eastern Europe, Economic Journal 53 (210/211) (Jun-Sep 1943): 202-211.

SPENCE, M. 2011. The Next Convergence: The Future of Economic Growth in a Multispeed World. New York: Farar, Straus \& Giroux.

UNEP 2011. Towards a Green Economy: Pathways to sustainable development and poverty eradication - A synthesis for policy makers. Nairobi: United Nations Environment Program. Available at: http://www.unep.org/greeneconomy/GreenEconomyReport/tabid/29846/Default. aspx

UNRUH, G.C. 2002. Escaping carbon lock-in, Energy Policy, 30 (4): 317-325.

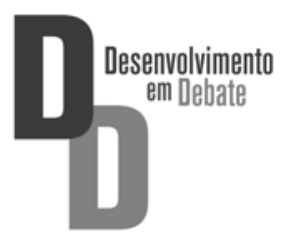

